\title{
Methods of Analysis by the U.S. Geological Survey Organic Geochemistry Research Group- Determination of Chloroacetanilide Herbicide Metabolites in Water Using High-Performance Liquid Chromatography-Diode Array Detection and High- Performance Liquid Chromatography/Mass \\ Spectrometry
}

By L.R. ZIMMERMAN, K.A. HOSTETLER, and E.M. THURMAN

Open-File Report 00-182

Lawrence, Kansas

2000 


\section{U.S. Department of the Interior}

Bruce Babbitt, Secretary

\section{U.S. Geological Survey}

Charles G. Groat, Director

The use of firm, trade, and brand names in this report is for identification purposes only and does not constitute endorsement by the U.S. Geological Survey.

For additional information write to:

District Chief

U.S. Geological Survey

4821 Quail Crest Place

Lawrence, KS 66049-3839
Copies of this report can be purchased from:

U.S. Geological Survey

Information Services

Building 810, Federal Center

Box 25286

Denver, CO 80225-0286 


\section{CONTENTS}

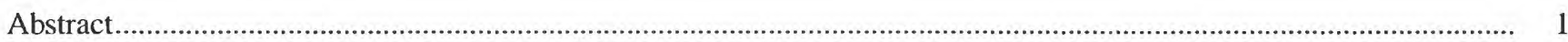

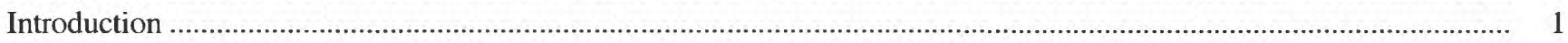

Determination of Chloroacetanilide Herbicide Metabolites in Water Using High-Performance Liquid

Chromatography-Diode Array Detection .............................................................................................................. 2

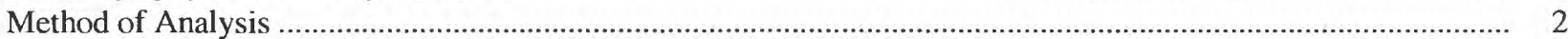

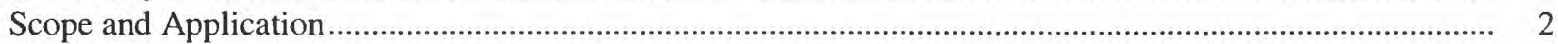

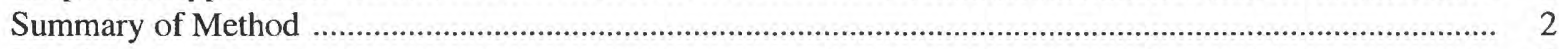

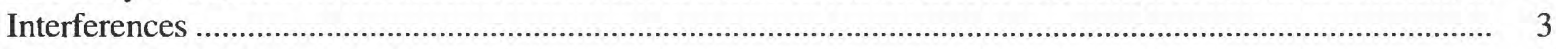

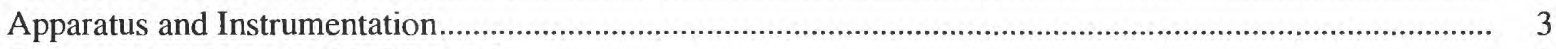

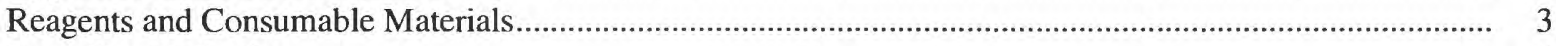

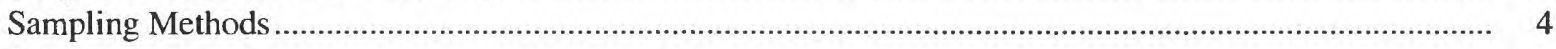

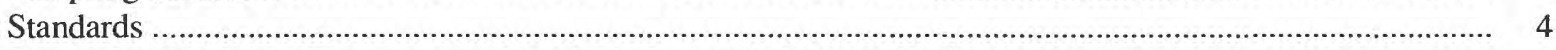

Evaluation of Liquid Chromatograph and Diode Array Detector Performance............................................ 4

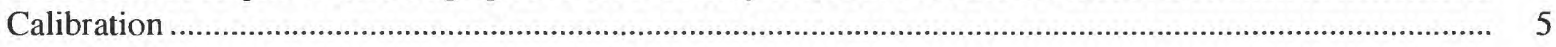

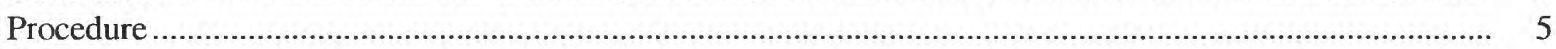

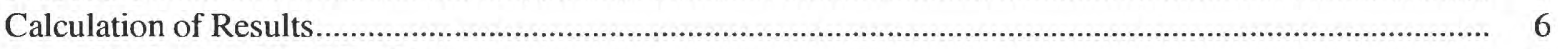

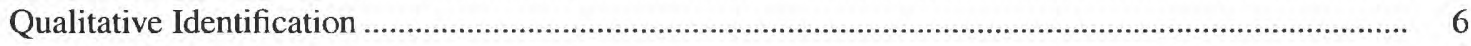

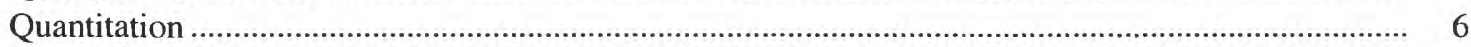

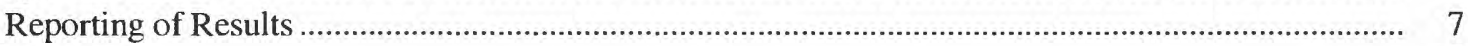

Method Performance ................................................................................................................................... 7

Determination of Chloroacetanilide Herbicide Metabolites in Water Using High-Performance Liquid Chromatography/

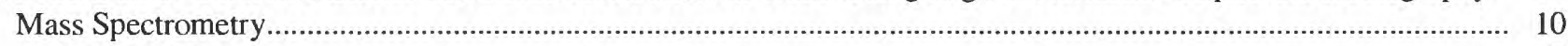

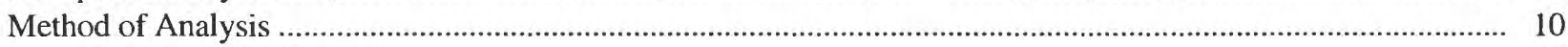

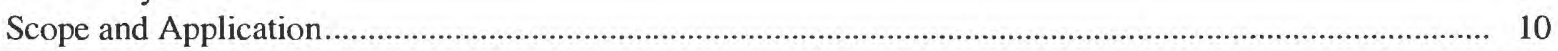

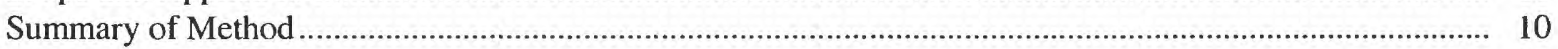

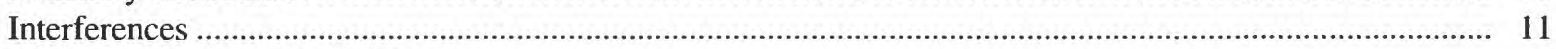

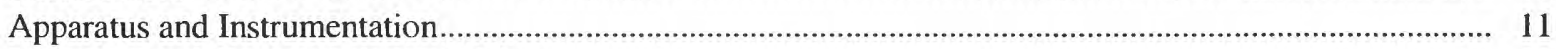

Reagents and Consumable Materials........................................................................................................... 11

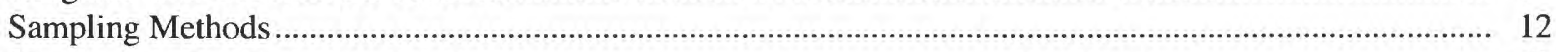

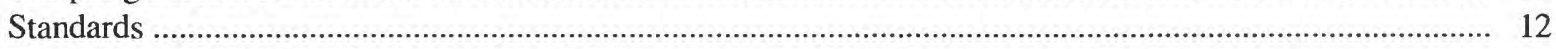

Evalutation of High-Performance Liquid Chromatography/Mass Spectrometry Performance ...................... 12

Evaluation of Liquid Chromatograph and Diode Array Detector Performance ..................................... 12

Evaluation of Mass Spectrometer Performance ......................................................................... 12

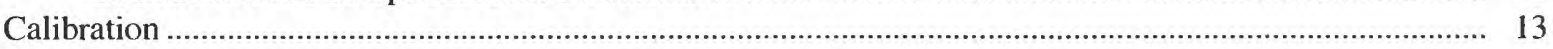

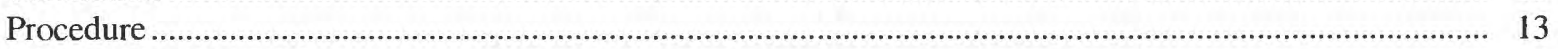

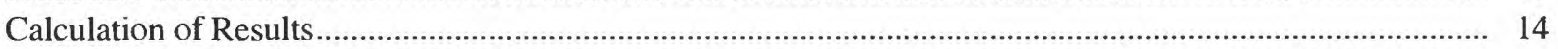

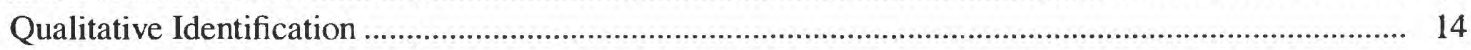

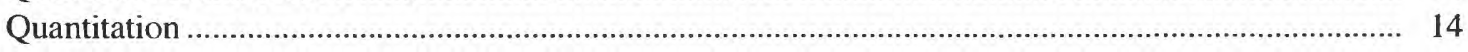

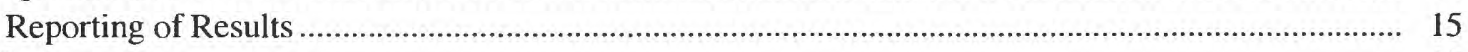

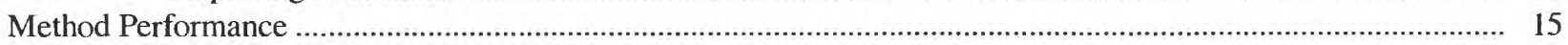

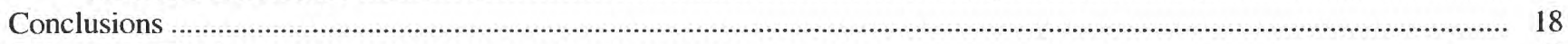

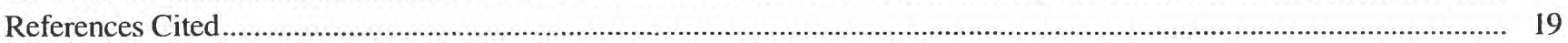

Appendix 1. Automated Solid-Phase Extraction Procedure Using Autotrace Workstation ................................................. 23

Appendix 2. Automated Solid-Phase Extraction Procedure Using Millilab 1A Workstation............................................ 25 
FIGURES

1. Typical chromatogram of a 2.0-microgram-per-liter control reagent-water sample using high-performance liquid chromatography-diode array detection.

2. Total ion chromatogram of a 0.05 -microgram-per-liter control reagent-water sample using high-

performance liquid chromatography/mass spectrometry.

3. Selected ion chromatogram of a 0.05 -microgram-per-liter control reagent-water sample for molecular ion 314 mass-to-charge ratio using high-performance liquid chromatography/mass spectrometry.

\section{TABLES}

1. Chloroacetanilide herbicide metabolite compounds suitable for determination using methods described and molecular weights

2. Retention times and relative retention times for chloroacetanilide herbicide metabolites and an internal standard analyzed using high-performance liquid chromatography-diode array detection.

3. Mean recovery of chloroacetanalide metabolites in reagent-water samples using high-performance liquid chromatography-diode array detection

4. Mean recovery of chloroacetanalide herbicide metabolites in surface-water samples using high-performance liquid chromatography-diode array detection

5. Mean recovery of chloroacetanalide herbicide metabolites in ground-water samples using high-performance liquid chromatography-diode array detection

6. Mean method detection limits for seven determinations of chloroacetanalide herbicide metabolites spiked at 0.25 microgram per liter in reagent water using high-performance liquid chromatography-diode array detection

7. Absolute recovery for 10 determinations of chloroacetanalide herbicide metabolites in reagent water using high-performance liquid chromatography-diode array detection

Retention times, relative retention times, and ions for chloroacetanilide herbicide metabolites analyzed using high-performance liquid chromatography/mass spectrometry

. Mean recovery of chloroacetanalide metabolites in reagent-water samples using high-performance liquid chromatography/mass spectrometry

Mean recovery of chloroacetanalide metabolites in surface-water samples using high-performance liquid chromatography/mass spectrometry

11. Mean recovery of chloroacetanalide metabolites in ground-water samples using high-performance liquid chromatography/mass spectrometry

12. Mean method detection limits for seven determinations of chloroacetanalide herbicide metabolites spiked at 0.05 microgram per liter in reagent water using high-performance liquid chromatography/mass spectrometry .. 
CONVERSION FACTORS, MISCELLANEOUS ABBREVIATIONS, AND ABBREVIATED WATER-QUALITY UNITS

\begin{tabular}{rcl}
\multicolumn{3}{c}{ Conversion Factors } \\
\hline Multiply & \multicolumn{1}{c}{ By } & To obtain \\
\hline ounce $(\mathrm{oz})$ & 0.02957 & liter \\
pound $(\mathrm{lb})$ & 453.6 & gram \\
pound per square inch $\left(\mathrm{lb} / \mathrm{in}^{2}\right)$ & 6.895 & kilopascal \\
\hline
\end{tabular}

Temperature can be converted to degrees Celsius $\left({ }^{\circ} \mathrm{C}\right)$ or degrees Fahrenheit $\left({ }^{\circ} \mathrm{F}\right)$ by the equations:

$$
\begin{aligned}
& { }^{\circ} \mathrm{C}=5 / 9\left({ }^{\circ} \mathrm{F}-32\right) \\
& { }^{\circ} \mathrm{F}=9 / 5\left({ }^{\circ} \mathrm{C}\right)+32 .
\end{aligned}
$$

\section{Miscellaneous Abbreviations}

cubic centimeter $\left(\mathrm{cm}^{3}\right)$

gram (g)

mass-to-charge ratio $(\mathrm{m} / \mathrm{z})$

meter $(\mathrm{m})$

micrometer $(\mu \mathrm{m})$

milliabsorbance units (mAU)

milligram (mg)

millimeter $(\mathrm{mm})$

millimole $(\mathrm{mM})$

millisecond (ms)

minute ( $\mathrm{min}$ )

nanogram (ng)

nanometer $(\mathrm{nm})$

volt (V)

\section{Abbreviated Water-Quality Units}

liter (L)

liter per minute $(\mathrm{L} / \mathrm{min})$

microgram per liter $(\mu \mathrm{g} / \mathrm{L})$

microliter $(\mu \mathrm{L})$

milligram per milliliter $(\mathrm{mg} / \mathrm{mL})$

milliliter $(\mathrm{mL})$

milliliter per minute $(\mathrm{mL} / \mathrm{min})$

nanogram per microliter $(\mathrm{ng} / \mu \mathrm{L})$ 
VI Determination of Chloroacetanilide Herbicide Metabolites in Water Using High-Performance Liquid Chromatography-Diode Array Detection and High-Performance Liquid Chromatography/Mass Spectrometry 


\title{
Methods of Analysis by the U.S. Geological Survey Organic Geochemistry Research Group-Determination of Chloroacetanilide Herbicide Metabolites in Water Using High-Performance Liquid Chromatography-Diode Array Detection and High-Performance Liquid Chromatography/Mass Spectrometry
}

\author{
By L.R. Zimmerman ${ }^{1}$, Kenneth A. Hostetler ${ }^{2}$, and E.M. Thurman ${ }^{3}$
}

\section{Abstract}

Analytical methods using high-performance liquid chromatography-diode array detection (HPLC-DAD) and high-performance liquid chromatography/mass spectrometry (HPLC/MS) were developed for the analysis of the following chloroacetanilide herbicide metabolites in water: acetochlor ethanesulfonic acid (ESA), acetochlor oxanilic acid (OXA), alachlor ESA, alachlor OXA, metolachlor ESA, and metolachlor OXA. Good precision and accuracy were demonstrated for both the HPLC-DAD and HPLC/MS methods in reagent water, surface water, and ground water. The mean HPLC-DAD recoveries of the chloroacetanilide herbicide metabolites from water samples spiked at $0.25,0.50$, and $2.0 \mu \mathrm{g} / \mathrm{L}$ (micrograms per liter) ranged from 84 to 112 percent, with relative standard deviations of 18 percent or less. The mean HPLC/MS recoveries of the metabolites from water samples spiked at $0.05,0.20$, and $2.0 \mu \mathrm{g} / \mathrm{L}$ ranged from 81 to 125 percent, with relative standard deviations of

\footnotetext{
${ }^{1}$ University of Kansas, Center for Research, Inc., Lawrence, Kansas.

${ }^{2}$ Formerly at University of Kansas, Center for Research, Inc., Lawrence, Kansas.

${ }^{3}$ U.S. Geological Survey, Lawrence, Kansas.
}

20 percent or less. The limit of quantitation (LOQ) for all metabolites using the HPLC-DAD method was $0.20 \mu \mathrm{g} / \mathrm{L}$, whereas the LOQ using the HPLC/MS method was $0.05 \mu \mathrm{g} / \mathrm{L}$. These metabolite-determination methods are valuable for acquiring information about water quality and the fate and transport of the parent chloroacetanilide herbicides in water.

\section{INTRODUCTION}

The chloroacetanilide herbicides - acetochlor, alachlor, and metolachlor - are an important class of herbicides in the United States. Together with the triazine compounds, chloroacetanilide herbicides compose the majority of pesticides applied in the Midwestern United States for control of weeds in corn, soybeans, and other row crops (Gianessi and Anderson, 1995). Alachlor and metolachlor have been used extensively for more than 20 years, whereas acetochlor application is relatively recent, having been applied extensively since March 1994 (Kolpin, Nations, and others, 1996). Chloroacetanilide herbicides have been shown to degrade more rapidly in soil than other herbicides, with half-lives from 15 to 30 days, whereas triazine half-lives are typically 30 to 60 days (Leonard, 1988).

Recent studies have reported the occurrence of chloroacetanilide metabolites in surface and ground 
water (Aga and others, 1996; Kolpin, Thurman, and Goolsby, 1996; Thurman and others, 1996; Kolpin and others, 1998). Kolpin and others (1998) found that metabolite concentrations in ground water may be at similar or even higher concentrations than the parent compounds, whereas in surface water the parent compounds are more abundant in the spring after application and are replaced gradually by metabolites during the remaining growing season. In understanding the fate and transport of parent compounds, reliable methods for the analysis of metabolites are vital. These methods also are important for analytical verification of the metabolites in toxicological studies.

High-performance liquid chromatography (HPLC) is needed for the analysis of chloroacetanilide herbicide metabolites because they are ionic compounds and are not sufficiently volatile for analysis by gas chromatography. HPLC-diode array detection (DAD) may be used in determining metabolite concentrations, especially when the water sample is relatively free of humic materials and ionic surfactants that can cause chromatographic interference. Coupling HPLC with mass spectrometry (MS) yields more qualitative data and lower detection limits than HPLC-DAD analysis alone.

This report describes the development of reliable HPLC-DAD and HPLC/MS methods for the analysis of ethanesulfonic acid (ESA) and oxanilic acid (OXA) metabolites of acetochlor, alachlor, and metolachlor in surface water and ground water. The HPLC-DAD method was derived from an analytical method for the analysis of alachlor ESA and alachlor OXA as reported by Macomber (1992). For application to the acetochlor and metolachlor metabolites, several modifications to that method were necessary to achieve chromatographic separation of metabolite peaks. The HPLC/MS method was derived from Ferrer and others (1997), with a minor modification to resolve coeluting peaks on the chromatogram, and was reported in Hostetler and Thurman (1999). Similarly, the analysis of the ESA and OXA metabolites of the newly registered acetanilide herbicide dimethenamid could be added to these methods of analysis, but performance data for these compounds are not included in this report. These methods supplement other methods of the U.S. Geological Survey (USGS) and have been implemented by the USGS Organic Geochemistry Research Group in Lawrence, Kansas.

The HPLC-DAD method of analysis described in this report has been assigned the method number
"O-2133-00." This unique code represents the HPLC-DAD automated method of analysis for organic compounds as described in this report and can be used to identify the method.

The HPLC/MS method of analysis described in this report has been assigned the method number "O-2134-00." This unique code represents the HPLC/MS automated method of analysis for organic compounds as described in this report and can be used to identify the method.

This report provides a detailed description of the methods, including the apparatus, reagents, instrument calibration, and the solid-phase extraction (SPE) procedure required for sample analysis. Estimated method detection limits, recoveries, and relative standard deviations for six chloroacetanilide herbicide metabolites for the HPLC-DAD and the HPLC/MS methods are presented.

\section{DETERMINATION OF CHLOROACETANILIDE HERBICIDE METABOLITES IN WATER USING HIGH-PERFORMANCE LIQUID CHROMATOGRAPHY-DIODE ARRAY DETECTION}

\section{Method of Analysis (0-2133-00)}

\section{Scope and Application}

HPLC-DAD is suitable for the determination of low concentrations (in micrograms per liter) of chloroacetanilide metabolites in natural water samples (table 1). Suspended particulate matter is removed from the samples by filtration, so this method is suitable only for dissolved-phase metabolites.

Metabolites were selected for analysis because of the extensive use of their parent herbicides in the United States and their importance to current (1999) studies being conducted by the USGS. The HPLC$\mathrm{DAD}$ method is suitable for concentrations ranging from 0.2 to $3.0 \mu \mathrm{g} / \mathrm{L}$ without dilution.

\section{Summary of Method}

Water samples are filtered at the collection site using baked, glass-fiber filters with $0.7-\mu \mathrm{m}$ pore diameter to remove suspended particulate matter. In the 
Table 1. Chloroacetanilide herbicide metabolite compounds suitable for determination using methods described and molecular weights

[ESA, ethanesulfonic acid; OXA, oxanilic acid]

\begin{tabular}{lc}
\hline \multicolumn{1}{c}{ Metabolite } & $\begin{array}{c}\text { Molecular weight } \\
\text { (atomic mass units) }\end{array}$ \\
\hline Acetochlor ESA & 317.4 \\
Acetochlor OXA & 268.3 \\
Alachlor ESA & 317.4 \\
Alachlor OXA & 268.3 \\
Metolachlor ESA & 331.4 \\
Metolachlor OXA & 281.3 \\
\hline
\end{tabular}

laboratory, filtered water samples are passed through a preconditioned $\mathrm{C}-18$ column. The $\mathrm{C}-18$ column is rinsed with ethyl acetate to remove interferring compounds. The adsorbed chloroacetanilide metabolites are removed from the $\mathrm{C}-18$ with methanol. The eluted solution is spiked with an internal standard, evaporated under nitrogen, and reconstituted. The sample components are separated, identified, and measured by injecting an aliquot of the concentrated extract into an HPLC equipped with a DAD. Compounds eluting from the LC columns are identified by comparing their retention times obtained by the measurement of control samples under the same conditions used for the collected samples. The concentration of each identified compound is measured by relating the DAD response produced by that compound to the DAD response produced by the internal standard.

\section{Interferences}

Samples with high concentrations of humic materials and ionic surfactants may cause chromatographic interference. Compounds that elute from the LC at the same time and are detected at the same wavelengths as the metabolites of interest also may interfere.

\section{Apparatus and Instrumentation}

- Analytical balances - Capable of accurately weighing $0.0100 \mathrm{~g} \pm 0.0001 \mathrm{~g}$.

- Autopipettes-20- to 200- $\mu \mathrm{L}$, variable-volume autopipettes with disposable tips (Rainin, Woburn, Massachusetts, or equivalent).

- Millilab 1A workstation-Automated SPE workstation with an online computer. The two syringe pumps on the fluidics module are equipped with a
5- and a 1-mL syringe (Waters, Milford,

Massachusetts).

- Multiple intake accessories (MIAs): Two MIAs are attached to the 5-mL syringe to increase sample capacity from 3 to 14 samples.

- Software: Millilab 1A software, version 3.0 (Waters, Milford, Massachusetts).

or

Tekmar six-position AutoTrace-Automated SPE workstation, (Tekmar-Dohrmann, Cincinnati, Ohio).

- Software: Tekmar AutoTrace Extraction software, version 1.33 (Tekmar-Dohrmann, Cincinnati, Ohio).

- Automated solvent evaporator-The heated bath temperature needs to be maintained at $50{ }^{\circ} \mathrm{C}$, and the nitrogen gas pressure at $15 \mathrm{lb} / \mathrm{in}^{2}$ (TurboVap LV Zymark Inc., Hopkinton, Massachusetts, or equivalent).

- Mechanical vortex

- Analytical columns-Phenomenex (Torrance, California) 5- $\mu \mathrm{m}, 250-\mathrm{x} 3-\mathrm{mm} \mathrm{C}-18$ column coupled to a Keystone (Bellefonte, Pennsylvania) $3-\mu \mathrm{m}$, 250- x 4.6-mm C-18 column.

- HPLC benchtop system-Hewlett Packard (Wilmington, Delaware), model 1090 with autoinjector and $\mathrm{DAD}$ detector.

- LC oven conditions: constant $60^{\circ} \mathrm{C}$.

- LC mobile phase: 60 percent, pH 7.0, 25-mm phosphate buffer, 35 percent methanol, and 5 percent acetonitrile solution with a flow rate of $0.6 \mathrm{~mL} / \mathrm{min}$.

- DAD conditions: Acquiring wavelengths 190 to $300 \mathrm{~nm}$.

- Data system - Computer and printer compatible with the HPLC system.

- Software-HPLC 3D ChemStation rev.A.03.03

(Hewlett Packard, Wilmington, Delaware) is used to acquire and store data and for peak integration.

\section{Reagents and Consumable Materials}

- Sample bottles-Baked 4-oz amber glass bottles (Boston round) with Teflon-lined lids.

- Sample filters-0.7- $\mu \mathrm{m}$ glass-fiber filters (Gilson, Middleton, Wisconsin, or equivalent).

- Reagent water-Generated by purification of tap water through activated charcoal filtration and deionization with a high-purity, mixed-bed resin, followed by another activated charcoal filtration, 
and finally distillation in an autostill (Wheaton, Millville, New Jersey, or equivalent).

- Analytical standards - Standards of the chloroacetanilide herbicide metabolites and the internal standard.

- SPE columns-C-18 Sep-Pak Plus, containing $360 \mathrm{mg}$ of $40-\mu \mathrm{m} \mathrm{C}-18$ bonded-silica packing (Waters, Milford, Massachusetts).

\section{or}

SPE columns-C-18 Sep-Pak Vac $6 \mathrm{~cm}^{3}$, containing $500 \mathrm{mg}$ of 50 - to $105-\mu \mathrm{m} \mathrm{C}-18$ bonded-silica packing (Waters, Milford, Massachusetts).

- Disposable snap-cap finish centrifuge tubes-10 mL (Kimble, Vineland, New Jersey, or equivalent).

- Solvents-

- Acetonitrile, American Chemical Society

(ACS) and HPLC grade.

- Ethyl acetate, HPLC grade.

- Methanol, ACS and HPLC grade.

- Sodium phosphate, dibasic anhydrous, ACS grade.

- Gas for evaporation-Nitrogen, ultrapure grade.

- Pasteur pipettes-Kimble, (Vineland, New Jersey), or equivalent.

- 0.1-mL autosampler vials-Plastic vial with glass cone insert and cap (Wheaton, Millville, New Jersey).

- Gases-

- LC solvent degasser-Helium, zero grade.

- LC autosampler gas-Air, zero grade.

\section{Sampling Methods}

Following USGS protocol, sampling methods capable of collecting water samples that accurately represent the water-quality characteristics of the surface water or ground water at a given time or location are used. Detailed descriptions of sampling methods used by the USGS for obtaining depth- and widthintegrated surface-water samples are given in Edwards and Glysson (1988) and Ward and Harr (1990). Similar descriptions of sampling methods for obtaining ground-water samples are given in Hardy and others (1989).

Briefly, sample-collection equipment are free of tubing, gaskets, and other components made of nonfluorinated plastic material that might leach interferences into water samples or sorb the pesticides and metabolites from the water. The water samples from each site are composited in a single container and filtered through a $0.7-\mu \mathrm{m}$ glass-fiber filter using a peristaltic pump. Filters are leached with about $200 \mathrm{~mL}$ of sample prior to filtration of the sample. The filtrate for analysis is collected in baked $125-\mathrm{mL}$ amber glass bottles with Teflon-lined lids. Samples are chilled immediately and shipped to the laboratory within 3 days of collection. At the laboratory, samples are logged in, assigned identification numbers, and refrigerated at $4 \pm 2{ }^{\circ} \mathrm{C}$ until extracted and analyzed.

\section{Standards}

- Stock standard solutions-Obtain chloroacetanilide herbicide metabolites and internal standard as pure materials from commercial vendors or chemical manufacturers. Prepare solutions of $1.00 \mathrm{mg} / \mathrm{mL}$ (corrected for purity) by accurately weighing, to the nearest $0.001 \mathrm{~g}, 50 \mathrm{mg}$ of the pure material in a $50-\mathrm{mL}$ volumetric flask and dilute with methanol. Store at less than $0{ }^{\circ} \mathrm{C}$. This solution is stable for about 24 months.

- Primary fortification standard-Prepare a $1.23-\mathrm{ng} / \mu \mathrm{L}$ concentration, primary fortification standard by combining appropriate volumes of the individual chloroacetanilide herbicide metabolites stock solutions in a 1-L volumetric flask. Dilute with methanol. Store at less than $0{ }^{\circ} \mathrm{C}$. This solution is stable for about 24 months.

- Internal standard solution-Prepare a solution of 2,4-dichlorophenoxyacetic acid in methanol at a concentration of $2.0 \mathrm{ng} / \mu \mathrm{L}$. Store at less than $0{ }^{\circ} \mathrm{C}$. This solution is stable for about 12 months.

- Calibration solutions-Prepare a series of calibration solutions using the primary fortification standard in reagent water (at concentrations ranging from 0.2 to $2.0 \mu \mathrm{g} / \mathrm{L}(0.2,0.5,1.0$, and $2.0 \mu \mathrm{g} / \mathrm{L})$. These will be processed through the extraction procedure (described in the "Procedure" section).

\section{Evaluation of Liquid Chromatograph and Diode Array Detector Performance}

LC performance is evaluated by background absorbance readings, peak shape, and pressure. Background absorbance signals should remain balanced and low and indicate that the columns have equilibrated with the mobile-phase flow and the absence of interferents. If peak shape deteriorates, the columns may need to be replaced. If the pressure reading is high, there may be a clog in the mobile-phase flow path, or the column compartment thermostat may not

4 Determination of Chloroacetanilide Herbicide Metabolites in Water Using High-Performance Liquid Chromatography-Diode Array Detection and High-Performance Liquid Chromatography/Mass Spectrometry 
have reached the required temperature yet. A variable DAD background signal indicates that the lamp may need replacement.

\section{Calibration}

- Acquire initial calibration data by using new columns, a new lamp, and freshly prepared calibration solutions. Use these data in the subsequent evaluation of HPLC-DAD performance.

- Acquire data for each calibration point by injecting $50 \mu \mathrm{L}$ of each extracted calibration solution into the HPLC according to the conditions already described. Calculate the relative retention time $\left(R R T_{c}\right)$ for each selected compound in the calibration solution or in a sample as follows:

$$
R R T_{c}=\frac{R T_{c}}{R T_{i}},
$$

where $R T_{c}=$ uncorrected retention time of the selected compound, and

$$
\begin{aligned}
R T_{i}= & \text { uncorrected retention time of the } \\
& \text { internal standard (2,4-dichlo- } \\
& \text { rophenoxyacetic acid). }
\end{aligned}
$$

See table 2 for an example of retention times and relative retention times.

- Initial calibration data are entered into a computer spreadsheet (Microsoft Excel, Microsoft, Inc., Seattle, Washington), and ratios of the peak heights to the internal standard peak height are calculated for each compound. The spreadsheet determines the slopes and $y$ intercepts for each

Table 2. Retention times and relative retention times for chloroacetanilide herbicide metabolites and an internal

\begin{tabular}{|c|c|c|}
\hline Compound & $\begin{array}{l}\text { Retention } \\
\text { time (min) }\end{array}$ & $\begin{array}{c}\text { Relative } \\
\text { retention } \\
\text { time }\end{array}$ \\
\hline \multicolumn{3}{|c|}{ Metabolites (in order of increasing retention time) } \\
\hline Alachlor OXA & 24.756 & 1.393 \\
\hline Acetochlor OXA & 25.702 & 1.446 \\
\hline Alachlor ESA & 30.014 & 1.688 \\
\hline Metolachlor OXA & 30.629 & 1.723 \\
\hline Acetochlor ESA & 31.854 & 1.792 \\
\hline Metolachlor ESA & 34.158 & 1.921 \\
\hline \multicolumn{3}{|c|}{ Internal standard } \\
\hline $\begin{array}{l}\text { 2,4-dichlorophenoxyacetic } \\
\text { acid }\end{array}$ & 17.778 & 1.000 \\
\hline
\end{tabular}
standard analyzed using high-performance liquid chromatography-diode array detection

[min, minute; ESA, ethanesulfonic acid; OXA, oxanilic acid] compound on the basis of plotting a correlation curve, with the internal-standard ratio for the compound on the $\mathrm{x}$ axis and the concentration of the standard used on the $y$ axis. The spreadsheet also determines the correlation coefficient $\left(\mathrm{r}^{2}\right)$ values.

- Initial calibration data acquired using new columns, possibly a new lamp, and freshly prepared calibration solutions are acceptable if the $r^{2}$ values for all curves are greater than or equal to 0.990 for all compounds and the apexes of adjacent compound peaks are separated.

- Subsequent daily laboratory control standards need to agree within \pm 20 percent of the actual concentration for the selected compound of interest. At least two laboratory control standards are analyzed with each sample set, one high calibration standard ranging from 0.50 to $2.0 \mu \mathrm{g} / \mathrm{L}$ and one low standard ranging from 0.20 to $0.50 \mu \mathrm{g} / \mathrm{L}$, to verify instrument response in each range.

\section{Procedure}

Two automated extraction systems are used in the laboratory. One method uses an automated Millilab IA workstation (Waters, Milford, Massachusetts), and the SPE cartridges (Sep-Pak) are obtained from Waters (Milford, Massachusetts). The SPE cartridges contain $360 \mathrm{mg}$ of $40-\mu \mathrm{m} \mathrm{C}-18-\left(\mathrm{C}_{18} \mathrm{H}_{37}\right)$ bonded silica.

An alternate SPE procedure used to extract samples is a Tekmar six-position AutoTrace (TekmarDohrmann, Cincinnati, Ohio) and SPE cartridges (Vac C-18 $6 \mathrm{~mL}$ ) obtained from Waters Corporation (Milford, Massachusetts). These vacuum cartridges contain $500 \mathrm{mg}$ of 55 - to $105-\mu \mathrm{m} \mathrm{C}-18-\left(\mathrm{C}_{18} \mathrm{H}_{37}\right)$ bonded silica. The same manufacturer of $\mathrm{C}$-18-bonded silica is used for both SPE procedures, but the different automation systems require different cartridge formats. The differing quantities of C-18-bonded silica and the different automation systems require minor differences in solvent volumes used in the extraction. The data in this report were produced using the automated Millilab lA workstation, but the Tekmar six-position AutoTrace procedure is listed in Appendix 1.

- Sample preparation - In the automation of sample extraction, the workstation (Waters Millilab, Milford, Massachusetts) requires $23 \mathrm{~mL}$ of sample to prime the pumps and rinse the tubing. Therefore, each sample must be $123 \mathrm{~mL}$, although only $100 \mathrm{~mL}$ passes through the SPE column. Conveniently, $123 \mathrm{~mL}$ is the exact volume that 
fits in the body of a 4-oz Boston round bottle. Should an environmental sample contain less than $123 \mathrm{~mL}$, distilled water is added to bring the volume to the required $123 \mathrm{~mL}$. Any volume added is recorded. An extraction sample set consists of nine samples, one duplicate sample, two standard control samples (one high concentration and one low concentration), and two blank control samples.

- Workstation preparation-Before a sample set is extracted on the workstation, each port is flushed with $15 \mathrm{~mL}$ of methanol:water (1:1) and then again with distilled water. All SPE columns, test tubes, solvents, internal standard solution, and samples then are loaded onto the instrument.

- Conditioning SPE columns-The workstation conditions each SPE column by sequentially passing $1 \mathrm{~mL}$ methanol, $1 \mathrm{~mL}$ ethyl acetate, $1 \mathrm{~mL}$ methanol, and $3 \mathrm{~mL}$ distilled water through each column at a flow rate of $20 \mathrm{~mL} / \mathrm{min}$ by positive pressure.

- Loading sample-Each sample port is flushed with $23 \mathrm{~mL}$ of sample, then $100 \mathrm{~mL}$ of sample are passed through the SPE column at a flow rate of $20 \mathrm{~mL} / \mathrm{min}$.

- Eluting interferring compounds from SPE columnEach SPE column is eluted with $3.5 \mathrm{~mL}$ ethyl acetate at a flow rate of $4 \mathrm{~mL} / \mathrm{min}$ to remove the parent herbicides and other potentially interfering compounds.

- Eluting metabolites from SPE column-Each SPE column is eluted with $3.5 \mathrm{~mL}$ methanol at a flow rate of $4 \mathrm{~mL} / \mathrm{min}$ to remove the chloroacetanalide herbicide metabolites into a $10-\mathrm{mL}$ glass centrifuge tube.

- Spiking of internal standard-After all the samples in a set have been loaded and eluted, each methanol eluate is spiked with $500 \mu \mathrm{L}$ of $0.2-n g / \mu \mathrm{L} 2$,4-dichlorophenoxyacetic acid solution. The internal standard is used to normalize injection-volume variation, as a retention-time reference, and for quantitation.

- Evaporation-The spiked solution then is evaporated under nitrogen in a water bath at $50{ }^{\circ} \mathrm{C}$.

- Reconstitution-The extracts are reconstituted with $75 \mu \mathrm{L}$ of a solution containing 60 percent, $\mathrm{pH} 7.0$, $25-\mathrm{mM}$ phosphate buffer and 40 percent methanol, and then are vortexed.

- Transfer to vials - Using a disposable Pasteur pipette, the eluted solution from the $10-\mathrm{mL}$ glass centrifuge tube is transferred to an appropriately labeled autosampler vial containing a $0.1-\mathrm{mL}$ insert for HPLC-DAD analysis. The autosampler vial is capped and stored at less than $0{ }^{\circ} \mathrm{C}$ until analysis by HPLC-DAD.

- Sample analysis and data evaluation-Ensure that HPLC-DAD conditions for the analysis of the selected metabolites in sample extracts are the same as those used in the analysis of the calibration solutions. Prior to the analysis of any sample extracts the HPLC-DAD must meet the performance criteria and the selected-metabolite calibration data must conform to the criteria set forth. Fifty (50) $\mu \mathrm{L}$ of the sample extract is injected, and data are acquired using the HPLC-DAD conditions described.

\section{Calculation of Results}

\section{Qualitative Identification}

- The expected retention time (RT) of the peak of the selected metabolite of interest needs to be within \pm 2 percent of the expected retention time on the basis of the $R R T_{c}$ obtained from the internalstandard analysis. The expected retention time is calculated as follows:

$$
R T=\left(R R T_{c}\right)\left(R T_{i}\right),
$$

where $R T=$ expected retention time of the selected metabolite,

$$
\begin{aligned}
R R T_{c}= & \begin{array}{l}
\text { relative retention time of the } \\
\text { selected metabolite, and }
\end{array} \\
R T_{i}= & \begin{array}{l}
\text { uncorrected retention time of the } \\
\text { internal standard. }
\end{array}
\end{aligned}
$$

- If there are multiple peaks that agree in retention time to a metabolite, then additional qualitative indentification can be made using spectral information obtained by the 3D ChemStation software on the HPLC-DAD instrument.

\section{Quantitation}

- The dilution factor is calculated as follows:

$$
D F=\left(\frac{123}{123-V_{n p}}\right)\left(\frac{123}{123+V_{a}}\right)
$$

where $D F=$ dilution factor,

$$
\begin{aligned}
V_{n p}= & \text { volume not pumped = volume, in } \\
& \mathrm{mL}, \text { not pumped through the SPE } \\
& \text { column, and }
\end{aligned}
$$




\section{$V_{a}=$ volume added $=$ volume, in $\mathrm{mL}$, of distilled water added to a sam- ple that contains less than $123 \mathrm{~mL}$.}

The dilution factor is incorporated into the calculation for determining the final concentration in the sample.

- If a selected metabolite has passed the aforementioned qualitative identification criteria, the concentration in the sample is calculated as follows:

$$
C=\left(\left(\frac{H_{c}}{H_{i}}\right)(m)+y\right)(D F),
$$

where $C=\quad$ concentration of the selected metabolite in the sample, in micrograms per liter;

$H_{c}=\quad$ peak height, in milliabsorbance units, for the selected metabolite identified;

$H_{i}=\quad$ peak height, in milliabsorbance units, for the internal standard;

$m=\quad$ slope of correlation curve between the selected metabolite and the internal standard from the original calibration data;

$y=\quad y$ intercept of correlation curve between the selected metabolite and the internal standard from the original calibration data; and $D F=\quad$ dilution factor as calculated in equation 3.

\section{Reporting of Results}

Chloroacetanalide herbicide metabolites are reported in concentrations ranging from 0.2 to $3.0 \mu \mathrm{g} / \mathrm{L}$. If the concentration is greater than $3.0 \mu \mathrm{g} / \mathrm{L}$, the sample is re-extracted with a 1:10 (sample:distilled water) dilution and re-analyzed for those compounds that were greater than $3.0 \mu \mathrm{g} / \mathrm{L}$. Linearity experiments have been conducted showing linear response curves from 0.2 to $10 \mu \mathrm{g} / \mathrm{L}$.

\section{Method Performance}

A reagent-water sample, a surface-water sample collected from Poison Creek in Valley County, Idaho, and a ground-water sample collected from a well in Valley County, Idaho, were used to test the method performance. The surface- and ground-water samples were collected in 45-L carboys and were split into twenty-one 123-mL samples. One set of seven samples was spiked with $0.25 \mu \mathrm{g} / \mathrm{L}$ of each chloroacetanalide metabolite of interest, one set with $0.50 \mu \mathrm{g} / \mathrm{L}$, and the other set of seven samples was spiked with $2.0 \mu \mathrm{g} / \mathrm{L}$. In addition, unspiked samples of surface and ground water were extracted and analyzed to determine background concentrations of the pesticides. All subsamples were analyzed in one laboratory (the USGS Organic Geochemistry Research Laboratory in Lawrence, Kansas) using one HPLCDAD system. Each sample set was extracted and analyzed on different days from November 1998 through January 1999, so comparison of different matrices and concentrations included bias from day-to-day variation. Method recoveries from the analyses are listed in tables 3, 4, and 5 .

Corrections for background concentrations: Neither surface- nor ground-water samples required correction for background concentrations of metabolites. All unspiked reagent-water samples also had no detections of metabolites.

Method detection limits (MDL's): An MDL is defined as the minimum concentration of a substance that can be identified, measured, and reported with a 99-percent confidence that the compound concentration is greater than zero. MDL's were determined according to procedures outlined by the U.S. Environmental Protection Agency (1992). Seven replicate samples of reagent water were spiked with $0.25 \mu \mathrm{g} / \mathrm{L}$ of each of the metabolites of interest and analyzed to determine MDL's (table 6). Each sample was analyzed on different days during November 1998 through January 1999, so day-to-day variation is included in the results.

The MDL was calculated using the following equation:

$$
M D L=(S)\left(t_{(n-1,1-\alpha=0.99)}\right),
$$

where $S=\quad$ standard deviation of replicate analysis, in micrograms per liter, at the spiked concentration;

$t_{(\mathrm{n}-1,1-\alpha=0.99)}=\quad$ Student's $t$-value for the 99percent confidence level with $n-1$ degrees of freedom (U.S. Environmental Protection Agency, 1992); and

$$
n=\quad \text { number of replicate analyses. }
$$

The estimated mean MDL's ranged from 0.09 to $0.17 \mu \mathrm{g} / \mathrm{L}$ (table 6). According to the U.S. Environmental Protection Agency (1992) procedure, the 
Table 3. Mean recovery of chloroacetanilide metabolites in reagent-water samples using high-performance liquid chromatography-diode array detection

[ $\mu \mathrm{g} / \mathrm{L}$, micrograms per liter; RSD, relative standard deviation: ESA, ethanesulfonic acid; OXA, oxanilic acid]

\begin{tabular}{|c|c|c|c|c|c|c|}
\hline \multirow[b]{3}{*}{ Metabolite } & \multicolumn{6}{|c|}{ Reagent water } \\
\hline & \multicolumn{2}{|c|}{$\begin{array}{l}\text { Seven replicate samples } \\
\text { spiked at } 0.25 \mu \mathrm{g} / \mathrm{L}\end{array}$} & \multicolumn{2}{|c|}{$\begin{array}{l}\text { Seven replicate samples } \\
\text { spiked at } 0.50 \mu \mathrm{g} / \mathrm{L}\end{array}$} & \multicolumn{2}{|c|}{$\begin{array}{c}\text { Seven replicate samples } \\
\text { spiked at } 2.0 \mu \mathrm{g} / \mathrm{L}\end{array}$} \\
\hline & $\begin{array}{c}\text { Mean } \\
\text { recovery } \\
\text { (percent) }\end{array}$ & $\begin{array}{c}\text { RSD } \\
\text { (percent) }\end{array}$ & $\begin{array}{c}\text { Mean } \\
\text { recovery } \\
\text { (percent) }\end{array}$ & $\begin{array}{c}\text { RSD } \\
\text { (percent) }\end{array}$ & $\begin{array}{c}\text { Mean } \\
\text { recovery } \\
\text { (percent) }\end{array}$ & $\begin{array}{c}\text { RSD } \\
\text { (percent) }\end{array}$ \\
\hline Acetochlor ESA & 112 & 16 & 104 & 9.0 & 105 & 2.3 \\
\hline Acetochlor OXA & 88 & 18 & 94 & 14 & 95 & 3.1 \\
\hline Alachlor ESA & 100 & 10 & 102 & 5.5 & 100 & 2.4 \\
\hline Alachlor OXA & 84 & 17 & 92 & 9.6 & 90 & 2.7 \\
\hline Metolachlor ESA & 108 & 10 & 104 & 7.3 & 105 & 3.2 \\
\hline Metolachlor OXA & 108 & 14 & 102 & 5.3 & 100 & 3.1 \\
\hline
\end{tabular}

Table 4. Mean recovery of chloroacetanalide herbicide metabolites in surface-water samples using high-performance liquid chromatography diode-array detection

[ $\mu \mathrm{g} / \mathrm{L}$, micrograms per liter; RSD, relative standard deviation; ESA, ethanesulfonic acid; OXA, oxanilic acid]

\begin{tabular}{|c|c|c|c|c|c|c|}
\hline \multirow[b]{3}{*}{ Metabolite } & \multicolumn{6}{|c|}{ Surface water } \\
\hline & \multicolumn{2}{|c|}{$\begin{array}{l}\text { Seven replicate samples } \\
\text { spiked at } 0.25 \mu \mathrm{g} / \mathrm{L}\end{array}$} & \multicolumn{2}{|c|}{$\begin{array}{l}\text { Sevel replicate samples } \\
\text { spiked at } 0.50 \mu \mathrm{g} / \mathrm{L}\end{array}$} & \multicolumn{2}{|c|}{$\begin{array}{l}\text { Seven replicate samples } \\
\text { spiked at } 2.0 \mu \mathrm{g} / \mathrm{L}\end{array}$} \\
\hline & $\begin{array}{c}\text { Mean } \\
\text { recovery } \\
\text { (percent) }\end{array}$ & $\begin{array}{c}\text { RSD } \\
\text { (percent) }\end{array}$ & $\begin{array}{c}\text { Mean } \\
\text { recovery } \\
\text { (percent) }\end{array}$ & $\begin{array}{c}\text { RSD } \\
\text { (percent) }\end{array}$ & $\begin{array}{c}\text { Mean } \\
\text { recovery } \\
\text { (percent) }\end{array}$ & $\begin{array}{c}\text { RSD } \\
\text { (percent) }\end{array}$ \\
\hline Acetochlor ESA & 100 & 16 & 104 & 8.0 & 100 & 5.4 \\
\hline Acetochlor OXA & 84 & 14 & 94 & 7.0 & 100 & 4.9 \\
\hline Alachlor ESA & 104 & 8.9 & 98 & 3.4 & 105 & 4.4 \\
\hline Alachlor OXA & 92 & 14 & 96 & 7.4 & 100 & 6.3 \\
\hline Metolachlor ESA & 108 & 12 & 102 & 4.9 & 105 & 4.6 \\
\hline Metolachlor OXA & 108 & 16 & 100 & 3.5 & 100 & 5.7 \\
\hline
\end{tabular}

Table 5. Mean recovery of chloroacetanilide herbicide metabolites in ground-water samples using high-performance liquid chromatography-diode array detection

[ $\mu \mathrm{g} / \mathrm{L}$, micrograms per liter; RSD, relative standard deviation; ESA, ethanesulfonic acid; OXA, oxanilic acid]

\begin{tabular}{|c|c|c|c|c|c|c|}
\hline \multirow[b]{3}{*}{ Metabolite } & \multicolumn{6}{|c|}{ Ground water } \\
\hline & \multicolumn{2}{|c|}{$\begin{array}{l}\text { Seven replicate samples } \\
\text { spiked at } 0.25 \mu \mathrm{g} / \mathrm{L}\end{array}$} & \multicolumn{2}{|c|}{$\begin{array}{l}\text { Sevel replicate samples } \\
\text { spiked at } 0.50 \mu \mathrm{g} / \mathrm{L}\end{array}$} & \multicolumn{2}{|c|}{$\begin{array}{l}\text { Seven replicate samples } \\
\text { spiked at } 2.0 \mu \mathrm{g} / \mathrm{L}\end{array}$} \\
\hline & $\begin{array}{c}\text { Mean } \\
\text { recovery } \\
\text { (percent) }\end{array}$ & $\begin{array}{c}\text { RSD } \\
\text { (percent) }\end{array}$ & $\begin{array}{c}\text { Mean } \\
\text { recovery } \\
\text { (percent) }\end{array}$ & $\begin{array}{c}\text { RSD } \\
\text { (percent) }\end{array}$ & $\begin{array}{c}\text { Mean } \\
\text { recovery } \\
\text { (percent) }\end{array}$ & $\begin{array}{c}\text { RSD } \\
\text { (percent) }\end{array}$ \\
\hline Acetochlor ESA & 105 & 18 & 107 & 8.4 & 102 & 3.8 \\
\hline Acetochlor OXA & 87 & 15 & 95 & 7.8 & 99 & 5.3 \\
\hline Alachlor ESA & 103 & 9.3 & 98 & 4.6 & 103 & 3.2 \\
\hline Alachlor OXA & 88 & 13 & 94 & 6.9 & 94 & 4.8 \\
\hline Metolachlor ESA & 102 & 12 & 103 & 5.0 & 98 & 4.1 \\
\hline Metolachlor OXA & 104 & 16 & 100 & 4.8 & 100 & 3.5 \\
\hline
\end{tabular}


Table 6. Mean method detection limits for seven determinations of chloroacetanilide herbicide metabolites spiked at 0.25 micrograms per liter in reagent water using high-performace liquid chromatography-diode array detection [MDL, method detection, $\mu \mathrm{g} / \mathrm{L}$, micrograms per liter, ESA, ethanesulfonic acid: OXA, oxanilic acid]

\begin{tabular}{lccc}
\hline \multicolumn{1}{c}{ Metabolite } & $\begin{array}{c}\text { Mean } \\
\text { observed } \\
\text { concentra- } \\
\text { tion }(\mu \mathrm{g} / \mathrm{L})\end{array}$ & $\begin{array}{c}\text { Mean } \\
\text { standard } \\
\text { deviation } \\
(\mu \mathrm{g} / \mathrm{L})\end{array}$ & $\begin{array}{c}\text { Mean MDL } \\
(\mu \mathrm{g} / \mathrm{L})\end{array}$ \\
\hline Acetochlor ESA & 0.28 & 0.16 & 0.15 \\
Acetochlor OXA & .22 & .18 & .17 \\
Alachlor ESA & .25 & .10 & .09 \\
Alachlor OXA & .21 & .17 & .16 \\
Metolachlor ESA & .27 & .10 & .09 \\
Metolachlor OXA & .27 & .14 & .13 \\
\hline
\end{tabular}

spiked concentrations should be no more than five times the estimated MDL. The spiked concentrations were within five times the MDL.

Mean recovery: Mean recovery in reagent-, surface-, and ground-water samples was determined by comparing the mean calculated concentration (see "Quantitation" section) from seven replicate samples to the spiked concentration. Mean recoveries were highest in reagent water spiked at $0.25 \mu \mathrm{g} / \mathrm{L}$ (table 3 ). Acetochlor OXA and alachlor OXA generally exhibited the lowest recoveries regardless of matrix. The mean recoveries of all compounds spiked at the concentrations in table 3 were combined to calculate the mean recovery for reagent-water samples. The mean recovery in reagent water at all spiked concentrations was 99.6 percent.

Extraction absolute recovery: Absolute recovery of each chloroacetanalide metabolite was determined by comparing samples processed using the aforementioned procedure versus solvent spiked with the metabolites injected directly into the HPLC-DAD. Metabolite peak heights were compared to internalstandard peak heights. Absolute recoveries are listed in table 7. Absolute recovery is different than mean recovery listed in tables 3-5 in that mean recovery is calculated from an initial calibration curve that is processed in the same manner as the samples, thus correcting for routine analyte losses.

Method discussion: SPE and recovery for chloroacetanilide metabolites have been discussed in
Table 7. Absolute recovery for 10 determinations of chloroacetanilide herbicide metabolites in reagent water using high-performance liquid chromatography-diode array detection

[ESA, ethanesulfonic acid; OXA, oxanilic acid]

\begin{tabular}{lc}
\hline \multicolumn{1}{c}{ Metabolite } & $\begin{array}{c}\text { Absolute recovery } \\
\text { (percent) }\end{array}$ \\
\hline Acetochlor ESA & 71 \\
Acetochlor OXA & 110 \\
Alachlor ESA & 76 \\
Alachlor OXA & 110 \\
Metolachlor ESA & 72 \\
Metolachlor OXA & 106 \\
\hline
\end{tabular}

previous work (Aga and others, 1994; Thurman and others, 1996; Ferrer and others, 1997). In those studies, chromatographic separation was achieved only for a few of the herbicide metabolites specified in this report. In the work described in this report, each control surface- and ground-water sample was spiked with a standard containing all the ionic chloroacetanilide metabolites of interest. For purposes of accuracy and precision, chromatographic separation of the metabolites was essential.

The phosphate buffer supplied sodium as a counter ion to the anionic metabolites, creating neutral species that interact with the column. Coupling two columns and maintaining the columns at $60^{\circ} \mathrm{C}$ yielded enough metabolite-peak resolution for peak-height quantitation. In this case, it is not known exactly why using two columns with different particle diameters $(5 \mu \mathrm{m}$ and $3 \mu \mathrm{m})$ and column diameters ( $3 \mathrm{~mm}$ and $4.6 \mathrm{~mm}$ ) gave better metabolite separation than using two identical columns. One hypothesis is that water capacity of the column is related to the particle diameter, giving rise to subtle differences in ionic interactions. The columns were configured so that the larger particle column was positioned before the smaller particle column for effective backpressure regulation (smaller phase thickness gives higher backpressure). The analytical wavelength was set at $210 \mathrm{~nm}$, and DAD spectra were stored for every integrated peak with a peak height greater than $0.5 \mathrm{mAU}$. Figure 1 shows a typical HPLC-DAD chromatogram of a $2.0-\mu \mathrm{g} / \mathrm{L}$ control reagent-water sample. 


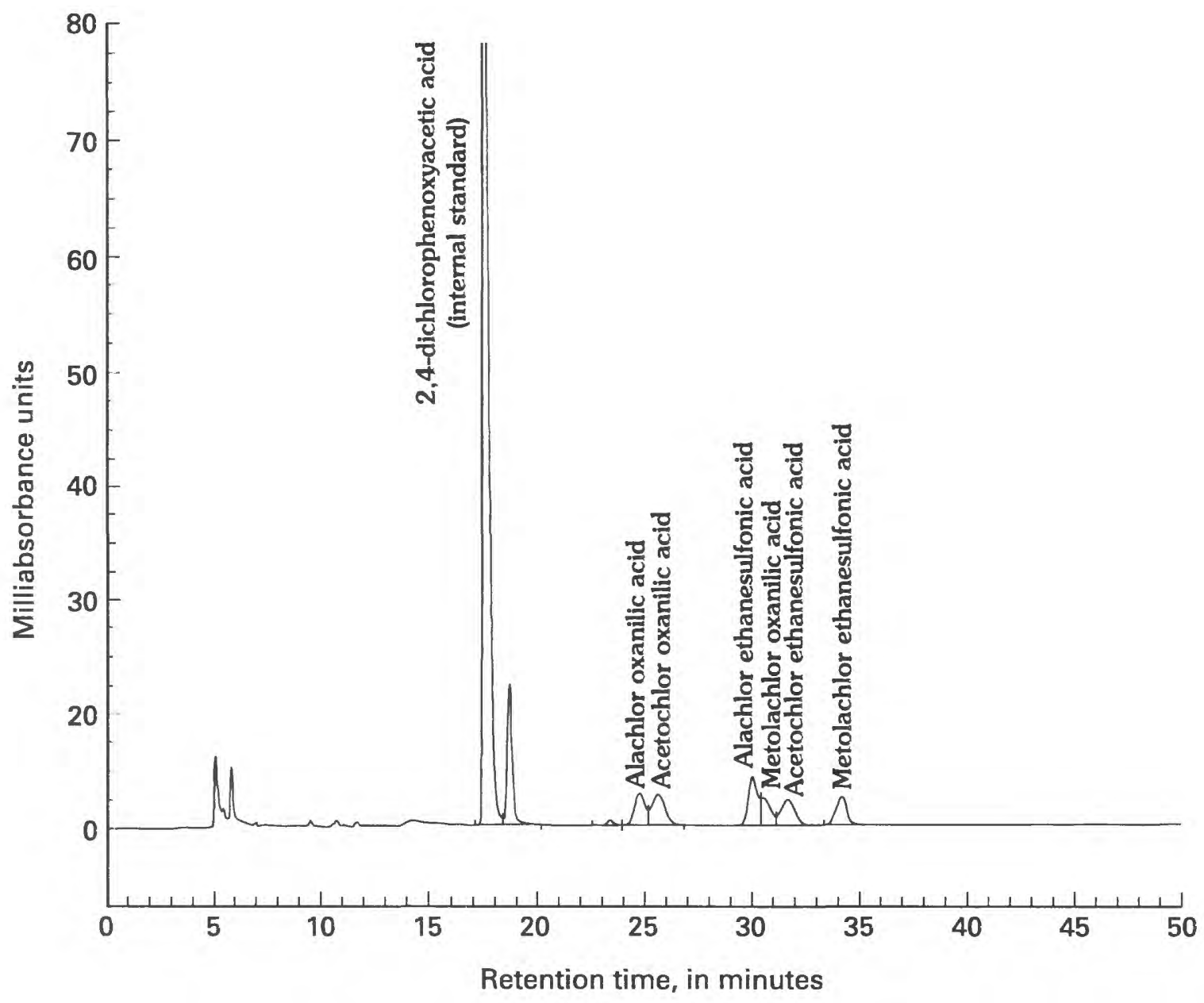

Figure 1. Typical chromatogram of a 2.0-microgram-per-liter control reagent-water sample using highperformance liquid chromatography-diode array detection.

\section{DETERMINATION OF \\ CHLOROACETANILIDE HERBICIDE METABOLITES IN WATER USING HIGH-PERFORMANCE LIQUID CHROMATOGRAPHY/MASS SPECTROMETRY}

\section{Method of Analysis $(0-2134-00)$}

\section{Scope and Application}

The HPLC/MS is suitable for the determination of low concentrations (in micrograms per liter) of chloroacetanilide metabolites in water samples (table 1). Suspended particulate matter is removed from the samples by filtration, so this method is suitable only for dissolved-phase metabolites.
Metabolites were selected for analyses because of the extensive use of their parent herbicides in the United States and their importance to current (1999) studies being conducted by the USGS. The HPLC/MS method is suitable for concentrations ranging from 0.05 to $5.0 \mu \mathrm{g} / \mathrm{L}$ without dilution.

\section{Summary of Method}

Water samples are filtered at the collection site using baked, glass-fiber filters with $0.7-\mu \mathrm{m}$ pore diameter to remove suspended particulate matter. In the laboratory, filtered water samples are passed through a preconditioned $\mathrm{C}-18$ column. The $\mathrm{C}-18$ column is rinsed with ethyl acetate to remove interferring compounds. The adsorbed chloroacetanilide metabolites are removed from the $\mathrm{C}-18$ with methanol. The eluted solution is spiked with an internal standard, evaporated under nitrogen, and reconstituted. The sample components are separated, identified, and measured by 
injecting an aliquot of the concentrated extract into an HPLC equipped with a DAD and a mass spectrometer detector. Compounds eluting from the LC columns are identified by comparing their retention times obtained by the measurement of control samples under the same conditions used for the collected samples. Compounds are identified further by selected fragment ions for compounds that can produce fragment ions. The concentration of each identified compound is measured by relating the MS response produced by that compound to the MS response produced by the internal standard.

\section{Interferences}

Compounds that elute from the $\mathrm{LC}$ at the same time and have identical ions as the metabolites of interest may interfere. Samples with considerable humic materials can cause interference with the ionization of the internal standard if they are eluting from the LC column at the same time.

\section{Apparatus and Instrumentation}

- Analytical balances-Capable of accurately weighing $0.0100 \mathrm{~g} \pm 0.0001 \mathrm{~g}$.

- Autopipettes-5- to 200- $\mu \mathrm{L}$, variable-volume autopipettes with disposable tips (Rainin, Woburn, Massachusetts, or equivalent).

- Millilab 1A workstation-Automated SPE workstation with an online computer. The two syringe pumps on the fluidics module are equipped with a 5- and a 1-mL syringe (Waters, Milford, Massachusetts).

- Multiple intake accessories (MIAs): Two MIAs are attached to the $5-\mathrm{mL}$ syringe to increase sample capacity from 3 to 14 .

- Software: Millilab 1A software, version 3.0 (Waters, Milford, Massachusetts).

or

Tekmar six-position AutoTrace-Automated SPE workstation (Tekmar-Dohrmann, Cincinnati, Ohio).

- Software: Tekmar AutoTrace Extraction software, version 1.33 (Tekmar-Dohrmann, Cincinnati, Ohio).

- Automated solvent evaporator-The heated bath temperature needs to be maintained at $50{ }^{\circ} \mathrm{C}$, and the nitrogen gas pressure at $15 \mathrm{lb} / \mathrm{in}^{2}$ (TurboVap
LV, Zymark Inc., Hopkinton, Massachusetts, or equivalent).

- Mechanical vortex

- Analytical columns-two Phenomenex 5- $\mu \mathrm{m}, 250$ $x$ 3-mm C-18 columns coupled to one (or two, if within backpressure limitations) Phenomenex 3$\mathrm{m}, 150-\mathrm{x} 2.0-\mathrm{mm} \mathrm{C}-18$ column.

- HPLC/MS benchtop system-Hewlett Packard (Wilmington, Delaware), model 1100 HPLC with autoinjector and MS detector.

- LC oven conditions: constant $70{ }^{\circ} \mathrm{C}$.

- LC mobile phase: 0.3 percent acetic acid, 24 percent methanol, 35.7 percent distilled water, and 40 percent acetonitrile solution with a flow rate of 0.3 to $0.4 \mathrm{~mL} / \mathrm{min}$.

- MS detector mode: electrospray in negative ion mode.

- Drying gas: flow was set at $6 \mathrm{~L} / \mathrm{min}$.

- Nebulizer pressure was $25 \mathrm{lbs} / \mathrm{in}^{2}$, the drying gas temperature was $300^{\circ} \mathrm{C}$, the capillary voltage was $3,100 \mathrm{~V}$, and the fragmenter voltage was $70 \mathrm{~V}$.

- Data system-Computer and printer compatible with the HPLC system.

- Software-HP LC/MSD ChemStation rev.A.06.03 (Hewlett Packard, Wilmington, Delaware) is used to acquire and store data and for peak integration.

\section{Reagents and Consumable Materials}

- Sample bottles-Baked 4-oz amber glass bottles (Boston round) with Teflon-lined lids.

- Sample filters - 0.7- $\mu \mathrm{m}$ glass-fiber filters (Gilson, Middleton, Wisconsin, or equivalent).

- Reagent water-generated by purification of tap water through activated charcoal filtration and deionization with a high-purity, mixed-bed resin, followed by another activated charcoal filtration, and finally distillation in an autostill (Wheaton, Millville, New Jersey, or equivalent).

- Analytical standards-Standards of the chloroacetanilide herbicide metabolites and the internal standard.

- SPE columns-C-18 Sep-Pak Plus, containing $360 \mathrm{mg}$ of $40-\mu \mathrm{m} \mathrm{C}-18$ bonded-silica packing (Waters, Milford, Massachusetts).

or SPE columns-C-18 Sep-Pak Vac $6 \mathrm{~cm}^{3}$, containing $500 \mathrm{mg}$ of 50 - to $105-\mu \mathrm{m} \mathrm{C}-18$ 
bonded-silica packing (Waters, Milford, Massachusetts).

- Disposable snap-cap finish centrifuge tubes-10 mL (Kimble, Vineland, New Jersey, or equivalent).

- Solvents-

- Acetonitrile, ACS and HPLC grade.

- Ethyl acetate, HPLC grade.

- Methanol, ACS and HPLC grade.

- Acetic acid, glacial-ACS grade.

- Gas for evaporation -nitrogen, ultrapure grade.

- Pasteur pipettes-(Kimble, Vineland, New Jersey, or equivalent)

- 0.1-mL autosampler vials-Plastic vial with glass cone insert and cap (Wheaton, Millville, New Jersey).

- Nebulizer gas-nitrogen, ultrapure grade.

\section{Sampling Methods}

Following USGS protocol, sampling methods capable of collecting water samples that accurately represent the water-quality characteristics of the surface water or ground water at a given time or location are used. Detailed descriptions of sampling methods used by the USGS for obtaining depth- and widthintegrated surface-water samples are given in Edwards and Glysson (1988) and Ward and Harr (1990). Similar descriptions of sampling methods for obtaining ground-water samples are given in Hardy and others (1989).

Briefly, sample-collection equipment are free of tubing, gaskets, and other components made of nonfluorinated plastic material that might leach interferences into water samples or sorb the pesticides and metabolites from the water. The water samples from each site are composited in a single container and filtered through a $0.7-\mu \mathrm{m}$ glass-fiber filter using a peristaltic pump. Filters are leached with about $200 \mathrm{~mL}$ of sample prior to filtration of the sample. The filtrate for analysis is collected in baked $125-\mathrm{mL}$ amber glass bottles with Teflon-lined lids. Samples are chilled immediately and shipped to the laboratory within 3 days of collection. At the laboratory, samples are logged in, assigned identification numbers, and refrigerated at $4 \pm 2{ }^{\circ} \mathrm{C}$ until extracted and analyzed.

\section{Standards}

- Stock standard solutions-Obtain chloroacetanilide herbicide metabolites and internal standard as pure materials from commercial vendors or chemical manufacturers. Prepare solutions of $1.00 \mathrm{mg} / \mathrm{mL}$ (corrected for purity) by accurately weighing, to the nearest $0.001 \mathrm{~g}, 50 \mathrm{mg}$ of the pure material in a $50-\mathrm{mL}$ volumetric flask and dilute with methanol. Store at less than $0{ }^{\circ} \mathrm{C}$. This solution is stable for about 24 months.

- Primary fortification standard-Prepare a $1.23-\mathrm{ng} / \mu \mathrm{L}$ concentration, primary fortification standard by combining appropriate volumes of the individual chloroacetanilide herbicide metabolites stock solutions in a $1-\mathrm{L}$ volumetric flask. Dilute with methanol. Store at less than $0{ }^{\circ} \mathrm{C}$. This solution is stable for about 24 months.

- Internal standard solution-Prepare a solution of 2,4-dichlorophenoxyacetic acid in methanol at a concentration of $2.0 \mathrm{ng} / \mu \mathrm{L}$. Store at less than $0{ }^{\circ} \mathrm{C}$. This solution is stable for about 12 months.

- Calibration solutions-Prepare a series of calibration solutions using the primary fortification standard in reagent water at concentrations ranging from 0.05 to $2.0 \mu \mathrm{g} / \mathrm{L}(0.05,0.10,0.20,0.50,1.0$, and $2.0 \mu \mathrm{g} / \mathrm{L}$ ).

\section{Evaluation of High-Performance Liquid Chromatography/Mass Spectrometry Performance}

\section{Evaluation of Liquid Chromatograph and Diode Array Detector Performance}

LC performance is evaluated by background absorbance readings, peak shape, and pressure. Background absorbance signals should remain balanced and low and indicate that the columns have equilibrated with the mobile-phase flow. If peak shape deteriorates, the columns may need to be replaced. If the pressure reading is high, there may be a clog in the mobile-phase flow path, or the column compartment thermostat may not have reached the required temperature yet. A variable DAD background signal indicates that the lamp may need replacement.

\section{Evaluation of Mass Spectrometer Performance}

- Tune the MS in electrospray in negative-ion mode before each HPLC/MS sample set (approximately 45 injections) using the procedure and software supplied by the manufacturer.

- For the first sample of a sample set, inject a solution of 0.3 percent acetic acid, 24 percent methanol, 
35.7 percent distilled water, and 40 percent acetonitrile solution to check for contamination.

\section{Calibration}

- Acquire initial calibration data by using new columns, a clean MS source, and freshly prepared calibration solutions. Use these data in the subsequent evaluation of HPLC/MS performance.

- Acquire data for each calibration solution by injecting $50 \mu \mathrm{L}$ of each solution into the HPLC/MS according to the conditions already described. Calculate the relative retention time for each selected compound $\left(R R T_{c}\right)$ in the calibration solution or in a sample using equation 1 . See table 8 for an example of retention times, relative retention times, and confirmation ions.

- Initial calibration data are entered into a computer spreadsheet (Microsoft Excel, Microsoft, Inc., Seattle, Washington), and ratios of the quantitation ion peak areas to the internal standard quantitation ion peak area are calculated for each compound. The spreadsheet determines the slopes and y intercepts for each compound by plotting the correlation curve with the internal standard ratio of a single compound on the $\mathrm{x}$ axis and the concentration of the standard used on the $y$ axis. The spreadsheet also determines the correlation coefficient $\left(r^{2}\right)$ values.

- Initial calibration data are acceptable if the $r^{2}$ value for all curves is greater than or equal to 0.990 for all compounds and the apex of adjacent compound peaks are separated.

- Subsequent daily laboratory control standards need to agree within \pm 20 percent of the actual concentration for the selected compound of interest. At least two laboratory control standards are analyzed with each sample set, one high calibration standard ranging from 0.50 to $2.0 \mu \mathrm{g} / \mathrm{L}$ and one low standard ranging from 0.05 to $0.20 \mu \mathrm{g} / \mathrm{L}$ to verify instrument response in each range.

\section{Procedure}

Two automated extraction systems are used in the laboratory. One method uses an automated Millilab 1 A workstation (Waters, Milford, Massachusetts), and SPE cartridges (Sep-Pak) obtained from Waters (Milford, Massachusetts). The SPE cartridges contain $360 \mathrm{mg}$ of $40-\mu \mathrm{m} \mathrm{C}-18-\left(\mathrm{C}_{18} \mathrm{H}_{37}\right)$ bonded silica.

An alternate SPE procedure used to extract samples is a Tekmar six-position AutoTrace (TekmarDohrmann, Cincinnati, Ohio) and SPE cartridges (Vac C-18 $6 \mathrm{~mL}$ ) obtained from Waters Corporation (Milford, Massachusetts). These vacuum cartridges contained $500 \mathrm{mg}$ of 55 - to $105-\mu \mathrm{m} \mathrm{C}-18-\left(\mathrm{C}_{18} \mathrm{H}_{37}\right)$ bonded silica. The same manufacturer of $\mathrm{C}-18$ bonded silica is used for both SPE procedures, but the different automation systems require different cartridge formats. The differing quantities of $\mathrm{C}-18$ bonded silica and the different automation systems require minor differences in solvent volumes used in the extraction. The data in this report were produced using the automated Millilab 1A workstation, but the Tekmar six-position AutoTrace procedure is listed in Appendix 1.

- Sample preparation-In the automation of sample extraction, the workstation (Waters Millilab, Milford, Massachusetts) requires $23 \mathrm{~mL}$ of sample to prime the pumps and rinse the tubing. Therefore, each sample must be $123 \mathrm{~mL}$, although only $100 \mathrm{~mL}$ passes through the SPE column.

Table 8. Retention times, relative retention times, and ions for chloroacetanilide herbicide metabolites analyzed using high-performance liquid chromatography/mass spectrometry [min, minute; m/z, mass-to-charge ratio; OXA, oxanilic acid; ESA, ethanesulfonic acid; --, not applicable]

\begin{tabular}{lcccc}
\hline \multicolumn{1}{c}{ Compound } & $\begin{array}{c}\text { Retention time } \\
(\mathbf{m i n})\end{array}$ & $\begin{array}{c}\text { Relative } \\
\text { retention time }\end{array}$ & $\begin{array}{c}\text { Quantitation } \\
\text { ion }(\mathbf{m} / \mathbf{z})\end{array}$ & $\begin{array}{c}\text { Fragmentation } \\
\text { ion }(\mathbf{s})(\mathbf{m} / \mathbf{z})\end{array}$ \\
\hline Metolachlor OXA & Metabolites (in order of increasing retention time) & \\
Alachlor OXA & 37.655 & 1.754 & 278 & 206 \\
Acetochlor OXA & 38.031 & 1.772 & 264 & 160,192 \\
Alachlor ESA & 38.258 & 1.782 & 264 & 146 \\
Metolachlor ESA & 48.368 & 2.253 & 314 & - \\
Acetochlor ESA & 49.283 & 2.296 & 328 & -- \\
& 49.532 & 2.308 & 314 & - \\
2,4-dichlorophenoxyacetic acid & 21.465 & Internal standard & 219 & 161 \\
\hline
\end{tabular}


Conveniently, $123 \mathrm{~mL}$ is the exact volume that fits in the body of a 4-oz Boston round bottle. Should an environmental sample contain less than $123 \mathrm{~mL}$, distilled water is added to bring the volume to the required $123 \mathrm{~mL}$. Any volume added is recorded. An extraction sample set consists of nine samples, one duplicate sample, two standard control samples (one high concentration and one low concentration), and two blank control samples.

- Workstation preparation-Before a sample set is extracted on the workstation, each port is flushed with $15 \mathrm{~mL}$ of methanol:water (1:1) and then again with distilled water. All SPE columns, test tubes, solvents, internal standard solution, and samples then are loaded onto the instrument.

- Conditioning SPE columns-The workstation conditions each SPE column by sequentially passing $1 \mathrm{~mL}$ methanol, $1 \mathrm{~mL}$ ethyl acetate, $1 \mathrm{~mL}$ methanol, and $3 \mathrm{~mL}$ distilled water through each column at a flow rate of $20 \mathrm{~mL} / \mathrm{min}$ by positive pressure.

- Loading sample-Each sample port is flushed with $23 \mathrm{~mL}$ of sample, then $100 \mathrm{~mL}$ of sample are passed through the SPE column at a flow rate of $20 \mathrm{~mL} / \mathrm{min}$.

- Eluting potential inteferring compounds from SPE column-Each SPE column is eluted with $3.5 \mathrm{~mL}$ ethyl acetate at a flow rate of $4 \mathrm{~mL} / \mathrm{min}$ to remove the parent herbicides and other potentially interferring compounds.

- Eluting metabolites from SPE column-Each SPE column is eluted with $3.5 \mathrm{~mL}$ methanol at a flow rate of $4 \mathrm{~mL} / \mathrm{min}$ to remove the chloroacetanalide herbicide metabolites into a 10 -mL glass centrifuge tube.

- Spiking of internal standard-After all the samples in a set have been loaded and eluted, each methanol eluate is spiked with $500 \mu \mathrm{L}$ of $0.2-\mathrm{ng} / \mu \mathrm{L} 2,4$ dichlorophenoxyacetic acid solution. The internal standard is used to normalize injectionvolume variation, as a retention-time reference, and for quantitation.

- Evaporation-The spiked solution then is evaporated under nitrogen in a water bath at $50{ }^{\circ} \mathrm{C}$.

- Reconstitution-The extracts are reconstituted with $75 \mu \mathrm{L}$ of a solution containing 0.3 percent acetic acid, 24 percent methanol, 35.7 percent distilled water, and 40 percent acetonitrile, and then are vortexed.

- Transfer to vials-Using a disposable Pasteur pipette, the eluted solution from the 10 -mL glass centrifuge tube is transferred to an appropriately labeled autosampler vial containing a $0.1-\mathrm{mL}$ insert for HPLC/MS analysis. The autosampler vial is capped and stored at less than $0{ }^{\circ} \mathrm{C}$ until analysis by HPLC/MS.

- Sample analysis and data evaluation-Ensure that HPLC/MS conditions for the analysis of the selected metabolites in sample extracts are the same as those used in the analysis of the calibration solutions. Prior to the analysis of any sample extracts, the HPLC/MS must meet the performance criteria and the selected-metabolite calibration data must conform to the criteria set forth. Fifty (50) $\mu \mathrm{L}$ of the sample extract is injected, and data are acquired using the HPLC/MS conditions described.

\section{Calculation of Results}

\section{Qualitative Identification}

- The expected retention time $(R T)$ of the peak of the quantitation ion for the selected metabolite of interest needs to be within \pm 2 percent of the expected retention time on the basis of the $R R T_{c}$ obtained from the internal-standard analysis. The expected retention time is calculated using equation 2.

- A metabolite is not identified unless it has the correct quantitation ion. If more than one ion is acquired for a metabolite, then additional verification is done by comparing the relative integrated abundance values of the significant ions monitored with the relative integrated abundance values obtained from the standard control samples. The relative ratios of the ions need to be within \pm 20 percent of the relative ratios of those obtained in the absence of any obvious interferences.

\section{Quantitation}

- The dilution factor is calculated using equation 3.

- If a selected metabolite has passed the aforementioned qualitative identification criteria, the concentration in the sample is calculated as follows: 


$$
C=\left(\left(\frac{A c}{A i}\right)(m)+y\right)(D F),
$$

$$
\begin{aligned}
& \text { where } C=\text { concentration of the selected } \\
& \text { metabolite in the sample, in } \\
& \text { micrograms per liter; } \\
& A_{c}=\text { peak area of the quantitation ion } \\
& \text { for the selected metabolite; } \\
& A_{i}=\text { peak area of the quantitation ion } \\
& \text { for the internal standard; } \\
& m=\text { slope of correlation curve } \\
& \text { between the selected metabolite } \\
& \text { and the internal standard from the } \\
& \text { original calibration data; } \\
& y=y \text { intercept of correlation curve } \\
& \text { between the selected metabolite } \\
& \text { and the internal standard from the } \\
& \text { original calibration data; and } \\
& D F=\text { dilution factor calculated using } \\
& \text { equation } 3 \text {. }
\end{aligned}
$$

\section{Reporting of Results}

Chloroacetanalide herbicide metabolites are reported in concentrations ranging from 0.05 to $5.0 \mu \mathrm{g} / \mathrm{L}$. If the concentration is greater than $5.0 \mu \mathrm{g} / \mathrm{L}$, the sample extract is diluted (volume increased to approximately $150 \mu \mathrm{L}$ with the reconstitution solution ( 0.3 percent acetic acid, 24 percent methanol, 35.7 percent distilled water, and 40 percent acetonitrile) and re-analyzed. If the concentration is greater than $10 \mu \mathrm{g} / \mathrm{L}$, the sample is re-extracted with a $1: 10$ (sample:distilled water) dilution and re-analyzed for those compounds that were greater than $10 \mu \mathrm{g} / \mathrm{L}$. Linearity experiments have been conducted showing linear response curves from 0.5 to $10 \mu \mathrm{g} / \mathrm{L}$.

\section{Method Performance}

A reagent-water sample, a surface-water sample collected from Poison Creek in Valley County, Idaho, and a ground-water sample collected from a well in Valley County, Idaho, were used to test the method performance. The surface- and ground-water samples were collected in 45-L carboys and were split into twenty-one 123-mL samples. One set of seven samples was spiked with $0.05 \mu \mathrm{g} / \mathrm{L}$ of each chloroacetanalide metabolite of interest, one set with $0.20 \mu \mathrm{g} / \mathrm{L}$, and the other set of seven samples was spiked with $2.0 \mu \mathrm{g} / \mathrm{L}$. In addition, unspiked samples of surface and ground water were extracted and analyzed to determine background concentrations of the pesticides. All subsamples were analyzed in one laboratory (the USGS Organic Geochemistry Research Laboratory in Lawrence, Kansas) using one HPLC/MS system. Each sample set was extracted and analyzed on different days from November 1998 through January 1999, so comparison of different matrices and concentrations included bias from dayto-day variation. Method recoveries from the analyses are listed in tables 9,10 , and 11 .

Corrections for background concentrations: Neither surface- nor ground-water samples required correction for background concentrations of metabolites. All unspiked reagent-water samples also had no detections of metabolites.

Method detection limits (MDL's): An MDL is defined as the minimum concentration of a substance that can be identified, measured, and reported with a 99-percent confidence that the compound concentration is greater than zero. MDL's were determined according to procedures outlined by the U.S. Environmental Protection Agency (1992). Seven replicate samples of reagent water spiked with $0.05 \mu \mathrm{g} / \mathrm{L}$ of each of the metabolites of interest and were analyzed to determine MDL's (table 12). Each sample was analyzed on different days during November 1998 through January 1999, so day-to-day variation is included in the results. The MDL was calculated using equation 5 .

The estimated mean MDL's ranged from 0.04 to $0.05 \mu \mathrm{g} / \mathrm{L}$ (table 12). According to the U.S. Environmental Protection Agency (1992) procedure, the spiked concentrations should be no more than five times the estimated MDL. The spiked concentrations were within five times the MDL.

Mean recovery: Mean recovery in reagent-, surface-, and ground-water samples was determined by comparing the mean calculated concentration (see "Quantitation" section) from seven replicate samples to the spiked concentration. Mean recoveries were highest in surface water at the $2.0-\mu \mathrm{g} / \mathrm{L}$ concentration (table 10), except for acetochlor ESA in reagent water spiked at 0.05 and $0.20 \mu \mathrm{g} / \mathrm{L}$ and in surface water spiked at $0.05 \mu \mathrm{g} / \mathrm{L}$ and for metoalchlor ESA in reagent water spiked at $2.0 \mu \mathrm{g} / \mathrm{L}$. Acetochlor OXA and alachlor OXA exhibited the lowest recoveries in reagent water, and acetochlor ESA and metolachlor ESA exhibited the highest recoveries regardless of matrix. The mean recoveries of all compounds spiked 
Table 9. Mean recovery of chloroacetanilide metabolites in reagent-water samples using high-performance liquid chromatography/mass spectrometry

[ $\mu \mathrm{g} / \mathrm{L}$, micrograms per liter; RSD, relative standard deviation; ESA, ethanesulfonic acid; OXA, oxanilic acid]

\begin{tabular}{|c|c|c|c|c|c|c|}
\hline \multirow[b]{3}{*}{ Metabolite } & \multicolumn{6}{|c|}{ Reagent water } \\
\hline & \multicolumn{2}{|c|}{$\begin{array}{l}\text { Seven replicate samples } \\
\text { spiked at } 0.05 \mu \mathrm{g} / \mathrm{L}\end{array}$} & \multicolumn{2}{|c|}{$\begin{array}{l}\text { Sevel replicate samples } \\
\text { spiked at } 0.20 \mu \mathrm{g} / \mathrm{L}\end{array}$} & \multicolumn{2}{|c|}{$\begin{array}{c}\text { Seven replicate samples } \\
\text { spiked at } 2.0 \mu \mathrm{g} / \mathrm{L}\end{array}$} \\
\hline & $\begin{array}{c}\text { Mean } \\
\text { recovery } \\
\text { (percent) }\end{array}$ & $\begin{array}{c}\text { RSD } \\
\text { (percent) }\end{array}$ & $\begin{array}{c}\text { Mean } \\
\text { recovery } \\
\text { (percent) }\end{array}$ & $\begin{array}{c}\text { RSD } \\
\text { (percent) }\end{array}$ & $\begin{array}{l}\text { Mean } \\
\text { recovery } \\
\text { (percent) }\end{array}$ & $\begin{array}{c}\text { RSD } \\
\text { (percent) }\end{array}$ \\
\hline Acetochlor ESA & 117 & 20 & 125 & 6.3 & 110 & 7.4 \\
\hline Acetochlor OXA & 84 & 12 & 85 & 9.6 & 86 & 5.9 \\
\hline Alachlor ESA & 95 & 19 & 100 & 5.4 & 100 & 4.9 \\
\hline Alachlor OXA & 81 & 11 & 85 & 11 & 88 & 6.4 \\
\hline Metolachlor ESA & 113 & 13 & 110 & 5.8 & 115 & 6.8 \\
\hline Metolachlor OXA & 110 & 11 & 105 & 5.0 & 104 & 5.7 \\
\hline
\end{tabular}

Table 10. Mean recovery of chloroacetanilide metabolites in surface-water samples using high-performance liquid chromatography/mass spectrometry

[ $\mu \mathrm{g} / \mathrm{L}$, micrograms per liter; RSD, relative standard deviation; ESA, ethanesulfonic acid; OXA, oxanilic acid]

\begin{tabular}{|c|c|c|c|c|c|c|}
\hline \multirow[b]{3}{*}{ Metabolite } & \multicolumn{6}{|c|}{ Surface water } \\
\hline & \multicolumn{2}{|c|}{$\begin{array}{l}\text { Seven replicate samples } \\
\text { spiked at } 0.05 \mu \mathrm{g} / \mathrm{L}\end{array}$} & \multicolumn{2}{|c|}{$\begin{array}{l}\text { Sevel replicate samples } \\
\text { spiked at } 0.20 \mu \mathrm{g} / \mathrm{L}\end{array}$} & \multicolumn{2}{|c|}{$\begin{array}{l}\text { Seven replicate samples } \\
\text { spiked at } 2.0 \mu \mathrm{g} / \mathrm{L}\end{array}$} \\
\hline & $\begin{array}{c}\text { Mean } \\
\text { recovery } \\
\text { (percent) }\end{array}$ & $\begin{array}{c}\text { RSD } \\
\text { (percent) }\end{array}$ & $\begin{array}{c}\text { Mean } \\
\text { recovery } \\
\text { (percent) }\end{array}$ & $\begin{array}{c}\text { RSD } \\
\text { (percent) }\end{array}$ & $\begin{array}{c}\text { Mean } \\
\text { recovery } \\
\text { (percent) }\end{array}$ & $\begin{array}{c}\text { RSD } \\
\text { (percent) }\end{array}$ \\
\hline Acetochlor ESA & 118 & 4.3 & 104 & 7.7 & 104 & 15 \\
\hline Acetochlor OXA & 90 & 8.1 & 101 & 6.1 & 111 & 11 \\
\hline Alachlor ESA & 81 & 19 & 95 & 7.1 & 109 & 13 \\
\hline Alachlor OXA & 90 & 10 & 99 & 6.2 & 109 & 10 \\
\hline Metolachlor ESA & 92 & 11 & 101 & 6.3 & 114 & 10 \\
\hline Metolachlor OXA & 90 & 9.5 & 100 & 5.9 & 110 & 12 \\
\hline
\end{tabular}

Table 11. Mean recovery of chloroacetanilide metabolites in ground-water samples using high-performace liquid chromatography/mass spectrometry

[ $\mu \mathrm{g} / \mathrm{L}$, micrograms per liter; RSD, relative standard deviation; ESA, ethanesulfonic acid; OXA, oxanilic acid]

\begin{tabular}{|c|c|c|c|c|c|c|}
\hline \multirow[b]{3}{*}{ Metabolite } & \multicolumn{6}{|c|}{ Ground water } \\
\hline & \multicolumn{2}{|c|}{$\begin{array}{l}\text { Seven replicate samples } \\
\text { spiked at } 0.05 \mu \mathrm{g} / \mathrm{L}\end{array}$} & \multicolumn{2}{|c|}{$\begin{array}{l}\text { Sevel replicate samples } \\
\text { spiked at } 0.20 \mu \mathrm{g} / \mathrm{L}\end{array}$} & \multicolumn{2}{|c|}{$\begin{array}{c}\text { Seven replicate samples } \\
\text { spiked at } 2.0 \mu \mathrm{g} / \mathrm{L}\end{array}$} \\
\hline & $\begin{array}{c}\text { Mean } \\
\text { recovery } \\
\text { (percent) }\end{array}$ & $\begin{array}{c}\text { RSD } \\
\text { (percent) }\end{array}$ & $\begin{array}{c}\text { Mean } \\
\text { recovery } \\
\text { (percent) }\end{array}$ & $\begin{array}{c}\text { RSD } \\
\text { (percent) }\end{array}$ & $\begin{array}{c}\text { Mean } \\
\text { recovery } \\
\text { (percent) }\end{array}$ & $\begin{array}{c}\text { RSD } \\
\text { (percent) }\end{array}$ \\
\hline Acetochlor ESA & 102 & 12 & 103 & 5.0 & 98 & 4.1 \\
\hline Acetochlor OXA & 95 & 9.3 & 98 & 4.6 & 103 & 3.2 \\
\hline Alachlor ESA & 104 & 16 & 100 & 4.8 & 100 & 3.5 \\
\hline Alachlor OXA & 85 & 8.3 & 95 & 7.8 & 99 & 5.3 \\
\hline Metolachlor ESA & 92 & 11 & 107 & 8.4 & 102 & 3.8 \\
\hline Metolachlor OXA & 95 & 12 & 94 & 6.9 & 94 & 4.8 \\
\hline
\end{tabular}


Table 12. Mean method detection limits for seven determinations of chloroacetanilide herbicide metabolites spiked at 0.05 microgram per liter in reagent water using high-performance liquid chromatography/mass spectrometry

$[\mu \mathrm{g} / \mathrm{L}$, micrograms per liter; MDL, method detection limit; ESA, ethanesulfonic acid; OXA, oxanilic acid]

\begin{tabular}{lccc}
\hline \multicolumn{1}{c}{ Metabolite } & $\begin{array}{c}\text { Mean } \\
\text { observed } \\
\text { concen- } \\
\text { tration } \\
(\mu \mathrm{g} / \mathrm{L})\end{array}$ & $\begin{array}{c}\text { Mean } \\
\text { standard } \\
\text { deviation } \\
(\mu \mathrm{g} / \mathrm{L})\end{array}$ & $\begin{array}{c}\text { Mean MDL } \\
(\mu \mathrm{g} / \mathrm{L})\end{array}$ \\
\hline Acetochlor ESA & 0.06 & 0.12 & 0.04 \\
Acetochlor OXA & .04 & .11 & .04 \\
Alachlor ESA & .05 & .19 & .05 \\
Alachlor OXA & .04 & .11 & .04 \\
Metolachlor ESA & .06 & .13 & .05 \\
Metolachlor OXA & .06 & .11 & .04 \\
\hline
\end{tabular}

at all concentrations in table 9 were combined to calculate the mean recovery for reagent-water samples. The mean recovery in reagent water at all spiked concentrations was 100.7 percent.
Method discussion: A HPLC/MS method for the analysis of ethanesulfonic acids and oxanilic acids of acetochlor, alachlor, and metolachlor was reported by Ferrer and others (1997). The described HPLC system used an 5- $\mu \mathrm{m}, 250-\mathrm{x}$ 3.0-mm C-18 column, with a mobile phase consisting of 0.3 percent acetic acid in 24 percent methanol, 36 percent distilled water, and 40 percent acetonitrile solution. With this configuration, peak resolution was not achieved for acetochlor ESA and alachlor ESA, which have the same quantitation ion (table 8). Thus, accurate quantitation of these metabolites was not possible. Chromatographic separation of acetochlor ESA and alachlor ESA was achieved with the same mobile phase by coupling two 5- $\mu \mathrm{m}, 250-\mathrm{x}$ 3.0-mm C-18 columns to one (or two, if backpressure permits) $3-\mu \mathrm{m}, 150-$ x 2.0-mm C-18 column. Figure 2 shows a total ion chromatogram (TIC) of a $0.05-\mu \mathrm{g} / \mathrm{L}$ control reagent-water sample. Figure 3 shows the extracted ion chromatogram for the molecular ion (314 mass-to-charge ratio) of acetochlor ESA and alachlor ESA with near baseline separation. The

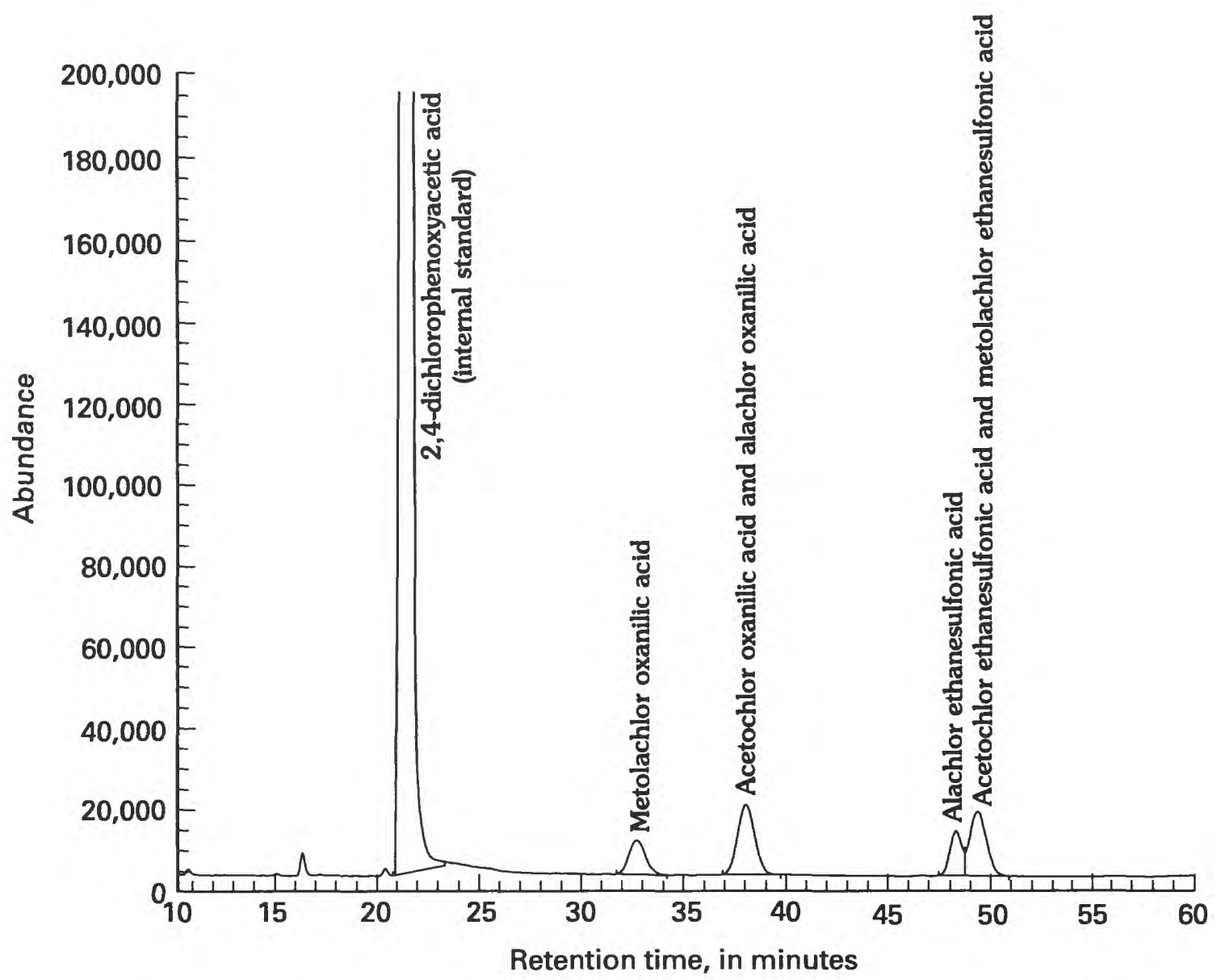

Figure 2. Total ion chromatogram (TIC) of a 0.05-microgram-per-liter control reagent-water sample using high-performance liquid chromatography/mass spectrometry. 


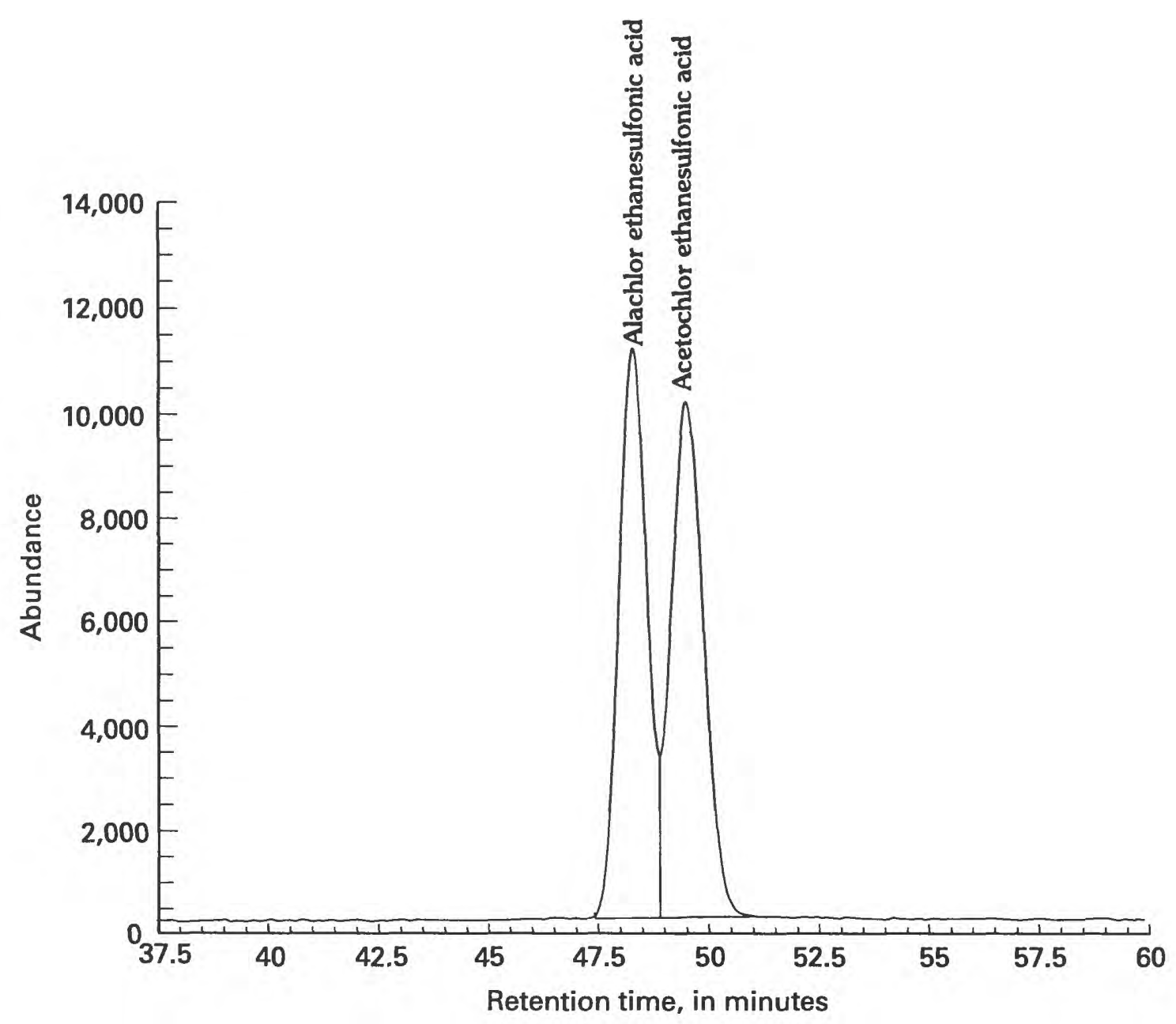

Figure 3. Selected ion chromatogram of a 0.05 -microgram-per-liter control reagent-water sample for molecular ion 314 mass-to-charge ratio using high-performance liquid chromatography/mass spectrometry.

elution order of the metabolites using the HPLC/MS method differs from that of the HPLC-DAD method because the $\mathrm{pH}$ of the respective mobile phases are different. They are different because the HPLC buffer is nonvolatile and not compatible with mass spectrometry.

2,4-dichlorophenoxy acid was used as the internal standard because it is amenable to negative ion electrospray and is readily available as a commercial standard. The use of deuterated surrogate standards is being investigated.

\section{CONCLUSIONS}

This report presents two methods for routine analysis of six chloracetanalide herbicide metabolites in natural water samples. From the data presented in this report, solid-phase extraction and determination by high-performance liquid chromatography-diode array detection (HPLC-DAD) or high-performance liquid chromatography/mass spectrometry (HPLC/MS) are shown to be sensitive and reliable methods for the determination of low concentrations. Good precision and accuracy were demonstrated for both the HPLCDAD and HPLC/MS methods in reagent water, surface water, and ground water. Method detection limits for the HPLC-DAD method ranged from 0.09 to $0.17 \mu \mathrm{g} / \mathrm{L}$. Method detection limits for the HPLC/MS method ranged from 0.04 to $0.05 \mu \mathrm{g} / \mathrm{L}$. The mean HPLC-DAD recoveries of the chloroacetanilide herbicide metabolites from water samples spiked at 0.25 , 0.50 , and $2.0 \mu \mathrm{g} / \mathrm{L}$ ranged from 84 to 112 percent, with relative standard deviations of 18 percent or less. The mean HPLC/MS recoveries of the metabolites from water samples spiked at $0.05,0.20$, and $2.0 \mu \mathrm{g} / \mathrm{L}$ ranged from 81 to 125 percent, with relative standard deviations of 20 percent or less. The limit of quanti- 
tation (LOQ) for all metabolites using the HPLC-DAD method was $0.20 \mu \mathrm{g} / \mathrm{L}$, whereas the LOQ using the HPLC/MS method was $0.05 \mu \mathrm{g} / \mathrm{L}$. Information about the fate and transport of the chloroacetanilide herbicides - acetochlor, alachlor, and metolachlor-in water can be acquired from the analysis of surfacewater runoff and ground water from wells. These methods also can be useful for water-quality determinations and analytical verification in toxicological studies.

\section{REFERENCES CITED}

Aga, D.S., Thurman, E.M., and Pomes, M.L., 1994, Determination of alachlor and its sulfonic acid metabolite in water by solid-phase extraction and enzyme-linked immunosorbent assay: Journal of Analytical Chemistry, v. 66, p. 1495-1499.

Aga, D.S., Thurman, E.M., Yockel, M.E., Zimmerman, L.R., and Williams, T.D., 1996, Identification of a new sulfonic acid metabolite of metolachlor in soil: Environmental Science and Technology, v. 30, p. 592-597.

Edwards, T.K., and Glysson, G.D., 1988, Field methods for measurement of fluvial sediment: U.S. Geological Survey Open-File Report 86-531, 118 p.

Ferrer, Imma, Thurman, E.M., and Barcelo, Damia, 1997. Identification of ionic chloroacetanilide herbicide metabolites in surface water and groundwater by HPLC/MS using negative ion spray: Journal of Analytical Chemistry, v. 69, p. 4547-4553.

Gianessi, L.P., and Anderson, J.E., 1995, Pesticide use in U.S. crop production - national data report: Washington, D.C., National Center for Food and Agricultural Policy, unpaginated.

Hardy, M.A., Leahy, P.P., and Alley, W.M., 1989, Well installation documentation and ground-water sampling protocols for the pilot National WaterQuality Assessment Program: U.S. Geological Survey Open-File Report 89-396, 36 p.

Hostetler, K.A., and Thurman, E.M., 1999, Determination of chloroacetanilide herbicide metabolites in water using high-performance liquid chromatography-diode array detection and high-performance liquid chroma- tography/mass spectrometry, in Morganwalp, D.W., and Buxton, H.T., eds., U.S. Geological Survey Toxic Substances Hydrology Program-Proceedings of the Technical Meeting, Charleston, South Carolina, March 8-12, 1999, volume 2 of 3-Contamination of hydrologic systems and related ecosystems: U.S. Geological Survey Water-Resources Investigations Report 99-4018B, p. 345-353.

Kolpin, D.W., Nations, B.K., Goolsby, D.A., and Thurman, E.M., 1996, Acetochlor in the hydrogeologic system in the Midwestern United States, 1994: Environmental Science and Technology, v. 30, p. 1459-1464.

Kolpin, D.W., Thurman, E.M., and Goolsby, D.A., 1996, Occurrence of selected pesticides and their metabolites in near-surface aquifers of the Midwestern U.S.: Environmental Science and Technology, v. 30, no. 5, p. 335-340.

Kolpin, D.W., Thurman, E.M., and Linhart, S.M., 1998, The environmental occurrence of herbicides - the importance of degradates in ground water: Archives of Environmental Contamination and Toxicology, v. 35, p. $1-6$.

Leonard, R.A., 1988, Herbicides in surface water, in Grover, R., ed., Environmental chemistry of herbicides - volume I: Boca Raton, Fla., CRC Press, p. 45-88.

Macomber, C., 1992, Determination of the ethane sulfonate metabolite of alachlor in water by high performance liquid chromatography: Journal of Agricultural and Food Chemistry, v. 40, p. 1450-1452.

Thurman, E.M., Goolsby, D.A., Aga, D.S., Pomes, M.L., and Meyer, M.T., 1996, Occurrence of alachlor and its sulfonated metabolite in rivers and reservoirs of the Midwestern U.S.: Environmental Science and Technology, v. 30, p. 569-574.

U.S. Environmental Protection Agency, 1992, Guidelines establishing test procedures for the analysis of pollutants (App. B, Part 136, Definition and procedures for the determination of the method detection limit): U.S. Code of Federal Regulations, Title 40, Revised as of July 1, 1992, p. 565-567.

Ward, J.R., and Harr, C.A., 1990, Methods for collection and processing of surface-water and bed-material samples for physical and chemical analyses: U.S. Geological Survey Open-File Report 90-140, 71 p. 
20 Determination of Chloroacetanilide Herbicide Metabolites in Water Using High-Performance Liquid Chromatography-Diode Array Detection and High-Performance Liquid Chromatography/Mass Spectrometry 


\section{APPENDICES}


22 Determination of Chloroacetanilide Herbicide Metabolites in Water Using High-Performance Liquid Chromatography-Diode Array Detection and High-Performance Liquid Chromatography/Mass Spectrometry 


\section{APPENDIX 1. AUTOMATED SOLID-PHASE EXTRACTION PROCEDURE USING AUTOTRACE WORKSTATION}

Tekmar AutoTrace Extraction Workstation 1.33

[mL, milliliter; min, minute]

AutoTrace Extraction Procedure : JK.123.MEOH

Estimated time for samples : 49.1 minutes

Date : December 12, 1999

Step 1 : Process six samples using the following procedure:

Step 2 : Condition column with $3 \mathrm{~mL}$ methanol into SOLVENT WASTE

Step 3 : Condition column with $3 \mathrm{~mL}$ ethyl acetate into SOLVENT WASTE

Step 4 : Condition column with $3 \mathrm{~mL}$ methanol into SOLVENT WASTE

Step 5 : Condition column with $3 \mathrm{~mL}$ distilled water into AQUEOUS WASTE

Step 6 : Wash syringe with $5 \mathrm{~mL}$ ethyl acetate

Step 7 : Load $125 \mathrm{~mL}$ of sample onto column

Step 8 : Dry column with gas for $0.5 \mathrm{~min}$

Step 9 : Condition column with $3.5 \mathrm{~mL}$ ethyl acetate into SOLVENT WASTE

Step 10 : Collect $3.5 \mathrm{~mL}$ fraction into sample tube using methanol

Step 11 : Dry column with gas for 3 minutes

Step 12 : END

\section{$\underline{\text { Setup Parameters }}$}

[mL/min, milliliters per minute; $\mathrm{mL}$, milliliter]

AutoTrace Extraction Workstation

\begin{tabular}{|c|c|c|c|}
\hline \multicolumn{2}{|c|}{ FLOW RATES } & Rinse flow: & 20.0 \\
\hline \multicolumn{2}{|c|}{$(\mathrm{mL} / \mathrm{min})$} & Elute flow: & 5.0 \\
\hline Condition flow: & 10.0 & Condition air push: & 15.0 \\
\hline Load flow: & 10.0 & Rinse air push: & 20.0 \\
\hline
\end{tabular}


Elute air push: $\quad 5.0$

Autowash volume: $\quad 1.00 \mathrm{~mL}$

WORKSTATION PARAMETERS

SOLID-PHASE EXTRACTION

PARAMETERS

Push delay:

Air factory:

1.0
Maximum elution volume:

Exhaust fan on:

Beeper on:
Name Solvents

Solvent 1 : Ethyl acetate

Solvent 2 : Methanol

Solvent 3 : Distilled water

Solvent 4 : not used

Solvent 5 : not used 
APPENDIX 2. AUTOMATED SOLID-PHASE EXTRACTION PROCEDURE USING MILLILAB IA WORKSTATION

\author{
Millilab 1A Solid-Phase Extraction Procedure \\ [mL, millileters; $\mathrm{mL} / \mathrm{min}$ : milliliters per minute]
}

$\begin{array}{ll}\text { Estimated time for samples : } \\ \text { Date } \\ \text { Tube name } & \text { Tube type } \\ \text { sample } & \text { PORT } \\ \text { elution } & \text { TUBE } \\ \text { splspike } & \text { TUBE } \\ \text { washprobe } & \text { TUBE } \\ \text { methelute } & \text { TUBE } \\ \text { Organic_waste } & \text { TUBE }\end{array}$

\title{
Element name Element type
}

Seppak+ $\quad$ CARTRIDGE

$\begin{array}{ll}\text { Port name } & \text { Liquid name } \\ \text { Syrlv1m1 } & \text { sample } \\ \text { Syrlv1m2 } & \text { sample } \\ \text { Syrlv1m3 } & \text { sample } \\ \text { Syrlv1m4 } & \text { sample } \\ \text { Syrlv2m1 } & \text { sample } \\ \text { Syrlv2m2 } & \text { sample } \\ \text { Syrlv2m3 } & \text { sample } \\ \text { Syrlv2m4 } & \text { sample }\end{array}$




\begin{tabular}{ll} 
Syrlv3m1 & sample \\
Syr1v3m2 & sample \\
Syr1v3m3 & sample \\
Syr1v3m4 & sample \\
Syr1v4m1 & sample \\
Syr1v4m2 & sample \\
Syr1v4m3 & distilled1 \\
Syr2v1 & distilled2 \\
Syr2v2 & ethyl acetate \\
Syr2v3 & methanol \\
Pump name & Syringe size \\
Pump 1 & 5.0 mL \\
Pump 2 & 1.0 mL \\
Reagent name & Liquid name \\
Reagent_1 & methanol \\
Reagent_2 & d10-phenanthrene \\
Reagent_3 & Not used \\
Reagent_4 & ethyl acetate \\
\hline
\end{tabular}

\section{Loop size}

$4 \mathrm{~mL}$

Technique name Technique parameters

(1) WASH PROBE Solvent $=$ distilled 1 Fill_Rate $=60 \mathrm{~mL} / \mathrm{min}$ Empty_Rate $=60 \mathrm{~mL} / \mathrm{min} \quad$ Volume $=20 \mathrm{~mL}$ Strokes $=4$

(2) SPE SELECT $\quad$ Cartridge $=$ Seppak + 
Technique name

(3) SPE LOAD

(4) SPE LOAD

(5)

SPE LOAD

SPE WASH

(6)

(7)

(8)

\section{Technique parameters}

Working_solvent $=$ distilled 1 Rate $=30 \mathrm{~mL} / \mathrm{min}$

Empty_rate $=20 \mathrm{~mL} / \mathrm{min}$ Volume $=1 \mathrm{~mL}$

Level $=0$

$$
\text { From }=\text { methanol }
$$

To $=$ Organic_waste

$\mathrm{Gap}=0.1 \mathrm{~mL}$

Working_solvent $=$ distilled 1 Rate $=30 \mathrm{~mL} / \mathrm{min}$

Empty_rate $=20 \mathrm{~mL} / \mathrm{min}$ Volume $=1 \mathrm{~mL}$

Level $=0 \quad$ From $=$ ethyl acetate To $=$ Organic $\_$waste

$\mathrm{Gap}=0.1 \mathrm{~mL}$

Working_solvent $=$ distilled 1 Rate $=30 \mathrm{~mL} / \mathrm{min}$

Empty_rate $=20 \mathrm{~mL} / \mathrm{min}$ Volume $=1 \mathrm{~mL}$

Level $=0 \quad$ From $=$ methanol $\quad$ To $=$ Organic_waste

Gap $=0.1 \mathrm{~mL}$

Solvent $=$ distilled $1 \quad$ Rate $=30 \mathrm{~mL} / \mathrm{min}$

Empty_rate $=20 \mathrm{~mL} / \mathrm{min} \quad$ Volume $=3 \mathrm{~mL}$

To $=$ Waste

Solvent $=$ sample

Fill Rate $=60 \mathrm{~mL} / \mathrm{min}$

Empty_rate $=60 \mathrm{~mL} / \mathrm{min} \quad$ Volume $=15 \mathrm{~mL} \quad$ Strokes $=3$

Solvent $=$ sample $\quad$ Rate $=30 \mathrm{~mL} / \mathrm{min}$

Empty_rate $=20 \mathrm{~mL} / \mathrm{min} \quad$ Volume $=100 \mathrm{~mL}$

To $=$ Waste 
Technique name

(9) WASH PROBE

(10)

ELEMENT PURGE Element $=$ Seppak + Dispose $=$ No $\quad$ Gas $=$ Purge 6

Level $=0$

Clear_time $=0.2 \mathrm{~min}$

Purge_time $=1 \mathrm{~min}$

To = Organic_waste

(11) SPE LOAD

(12) GAS PURGE

Gas $=$ Purge 6 To $=$ Organic_waste Level $=900$

Clear_time $=0 \mathrm{~min}$

Purge_time $=0.4 \mathrm{~min}$

(13) $\quad$ ELEMENT PURGE Element $=$ Seppak + Dispose $=$ No $\quad$ Gas $=$ Purge 6

Level $=0 \quad$ Clear_time $=0 \mathrm{~min}$

Purge_time $=0.3 \mathrm{~min}$ To $=$ elution

(14) SPE LOAD

Working_solvent $=$ ethyl acetate $\quad$ Rate $=4.0 \mathrm{~mL} / \mathrm{min}$

Empty_rate $=4.0 \mathrm{~mL} / \mathrm{min} \quad$ Volume $=3.5 \mathrm{~mL}$

Level $=0 \quad$ From $=$ methanol $\quad$ To $=$ methelut $\quad$ Gap $=0.1 \mathrm{~mL}$ 
(15) BATCH+PIPETTE Working_solvent $=$ ethyl acetate Fill_rate $=4 \mathrm{~mL} / \mathrm{min}$

Empty_Rate $=4 \mathrm{~mL} / \mathrm{min} \quad$ Asperate_level $=60$

Dispense_level $=560$ Volume $=0.5 \mathrm{~mL} \quad$ Gap $=0.1 \mathrm{~mL}$

From $=\mathrm{d} 10-$ phenan $\quad$ To $=$ elution $\quad$ Sample_count $=$ All

(16)

WASH PROBE

Solvent $=$ ethyl acetate

Fill_Rate $=6.0 \mathrm{~mL} / \mathrm{min}$

Empty_Rate $=6.0 \mathrm{~mL} / \mathrm{min} \quad$ Volume $=2 \mathrm{~mL}$

Strokes $=4$

(17) MIX

Working_solvent $=$ ethyl acetate

Fill_Rate $=6.0 \mathrm{~mL} / \mathrm{min}$

Empty_Rate $=6.0 \mathrm{~mL} / \mathrm{min} \quad$ Asperate_level $=250$

Dispense_level $=300 \quad$ Volume $=2.5 \mathrm{~mL}$

Gap $=0.1 \mathrm{~mL}$ Count $=2 \quad$ To $=$ elution

(18) WASH PROBE

Solvent $=$ ethyl acetate

Fill_Rate $=6.0 \mathrm{~mL} / \mathrm{min}$

Empty_Rate $=6.0 \mathrm{~mL} / \mathrm{min} \quad$ Volume $=2 \mathrm{~mL}$

Strokes $=4$

(19) PIPETTE

Working_solvent $=$ ethyl acetate

Fill_Rate $=4.0 \mathrm{~mL} / \mathrm{min}$

Empty_Rate $=4.0 \mathrm{~mL} / \mathrm{min} \quad$ Asperate_level $=270$

Dispense_level $=550$ Volume $=4 \mathrm{~mL}$

Gap $=0.2 \mathrm{~mL} \quad$ From $=$ elution $\quad$ To $=$ Splspike 
Technique name

(20) MIX

(21) GAS PURGE

(22) BUBBLE MIX

(23)

WASH PROBE

(24)

\section{Technique parameters}

Working_solvent $=$ ethyl acetate

Fill_Rate $=6.0 \mathrm{~mL} / \mathrm{min} \quad$ Empty_Rate $=6.0 \mathrm{~mL} / \mathrm{min}$

Asperate_level $=150$ Dispense_level $=150$

Volume $=3 \mathrm{~mL} \quad$ Gap $=0.1 \mathrm{~mL}$ Count $=1$

To $=$ Washprobe

Gas = Purge $6 \quad$ To $=$ Organic_waste $\quad$ Level $=900$

Clear_time $=0 \mathrm{~min} \quad$ Purge_time $=0.3 \mathrm{~min}$

Gas $=$ Purge $6 \quad$ To $=$ Washprobe $\quad$ Level $=0$

Clear_time $=0 \mathrm{~min}$ Purge_time $=0.3 \mathrm{~min}$

Solvent $=$ ethyl acetate $\quad$ Fill_Rate $=6.0 \mathrm{~mL} / \mathrm{min}$

Empty_Rate $=6.0 \mathrm{~mL} / \mathrm{min} \quad$ Volume $=1 \mathrm{~mL}$

Strokes $=2$

Dispose $=$ No 